\title{
The $\mathrm{CO}_{2}$ integral emission by the megacity of St Petersburg as quantified from ground-based FTIR measurements combined with dispersion modelling
}

\author{
Dmitry V. Ionov ${ }^{1}$, Maria V. Makarova ${ }^{1}$, Frank Hase ${ }^{2}$, Stefani C. Foka ${ }^{1}$, Vladimir S. Kostsov ${ }^{1}$, Carlos Alberti ${ }^{2}$, \\ Thomas Blumenstock $^{2}$, Thorsten Warneke ${ }^{3}$, and Yana A. Virolainen ${ }^{1}$ \\ ${ }^{1}$ Department of Atmospheric Physics, Faculty of Physics, St Petersburg State University, St Petersburg, Russia \\ ${ }^{2}$ Institute of Meteorology and Climate Research (IMK-ASF), Karlsruhe Institute of Technology (KIT), Karlsruhe, Germany \\ ${ }^{3}$ Institute of Environmental Physics and Institute of Remote Sensing, University of Bremen, Bremen, Germany
}

Correspondence: Dmitry V. Ionov (d.ionov@spbu.ru), Frank Hase (frank.hase@kit.edu), and Maria V. Makarova

(m.makarova@spbu.ru)

Received: 10 November 2020 - Discussion started: 2 February 2021

Revised: 28 April 2021 - Accepted: 23 June 2021 - Published: 20 July 2021

\begin{abstract}
The anthropogenic impact is a major factor of climate change, which is highest in industrial regions and modern megacities. Megacities are a significant source of emissions of various substances into the atmosphere, including $\mathrm{CO}_{2}$ which is the most important anthropogenic greenhouse gas. In 2019 and 2020, the mobile experiment EMME (Emission Monitoring Mobile Experiment) was carried out on the territory of St Petersburg which is the second-largest industrial city in Russia with a population of more than 5 million people. In 2020, several measurement data sets were obtained during the lockdown period caused by the COVID19 (COronaVIrus Disease of 2019) pandemic. One of the goals of EMME was to evaluate the $\mathrm{CO}_{2}$ emission from the St Petersburg agglomeration. Previously, the $\mathrm{CO}_{2}$ area flux has been obtained from the data of the EMME-2019 experiment using the mass balance approach. The value of the $\mathrm{CO}_{2}$ area flux for St Petersburg has been estimated as being $89 \pm 28 \mathrm{kt} \mathrm{km}^{-2} \mathrm{yr}^{-1}$, which is 3 times higher than the corresponding value reported in the official municipal inventory. The present study is focused on the derivation of the integral $\mathrm{CO}_{2}$ emission from St Petersburg by coupling the results of the EMME observational campaigns of 2019 and 2020 and the HYSPLIT (HYbrid Single-Particle Lagrangian Integrated Trajectories) model. The ODIAC (OpenData Inventory for Anthropogenic $\mathrm{CO}_{2}$ ) database is used as the source of the a priori information on the $\mathrm{CO}_{2}$ emissions for the territory of St Petersburg. The most important find-
\end{abstract}

ing of the present study, based on the analysis of two observational campaigns, is a significantly higher $\mathrm{CO}_{2}$ emission from the megacity of St Petersburg compared to the data of municipal inventory, i.e. $\sim 75800 \pm 5400 \mathrm{kt} \mathrm{yr}^{-1}$ for 2019 and $\sim 68400 \pm 7100 \mathrm{kt} \mathrm{yr}^{-1}$ for 2020 versus $\sim 30000 \mathrm{kt} \mathrm{yr}^{-1}$ reported by official inventory. The comparison of the $\mathrm{CO}_{2}$ emissions obtained during the COVID-19 lockdown period in 2020 to the results obtained during the same period of 2019 demonstrated the decrease in emissions of $10 \%$ or $7400 \mathrm{kt} \mathrm{yr}^{-1}$.

\section{Introduction}

Accurate quantitative assessment of anthropogenic emissions into the atmosphere is necessary for studying the mechanisms and factors that determine the impact of changes in atmospheric composition on climate, ecosystems and human health. Also, such an assessment is important for the development and control of compliance of the national policies in the field of environmental and climate protection to international agreements, regulations and standards (Pacala et al., 2010; Ciais et al., 2015; UNFCCC, 2015). In 2018, World Meteorological Organization (WMO) established the IG3IS division (Integrated Global Greenhouse Gas Information System). Its activities are related to international efforts relevant to the implementation of the Paris Agreement under the United Na- 
tions Framework Convention on Climate Change (UNFCCC, 2015). The main goal of IG3IS is "to expand the observational capacity for greenhouse gases (GHGs), extend it to the regional and urban domains, and develop the information systems and modelling frameworks to provide information about GHG emissions to society" (IG3IS, 2020).

According to statistics for 2018 (UN, 2021), 4.2 billion people or about $55 \%$ of the world's population live in cities. Urban areas are responsible for more than $70 \%$ of global energy-related $\mathrm{CO}_{2}$ emissions (Canadell et al., 2010). The vast majority of anthropogenic $\mathrm{CO}_{2}$ emissions in developed countries are associated with the burning of fossil fuels (FFs) and can be estimated with good accuracy on the basis of the total fuel consumption. At the same time, available data on regional and local emissions have a significantly lower level of confidence (Ciais et al., 2015; Bréon et al., 2015; Kuhlmann et al., 2019). Usually, to check the accuracy of the $\mathrm{CO}_{2}$ emission inventories (the so-called bottom-up data), the independent top-down approach is applied, which is based on a combination of atmospheric observations and numerical simulations. Currently, efforts in this direction are being made by international scientific communities in the framework of such large-scale projects as, for example, the VERIFY project (https://verify.lsce.ipsl.fr/, last access: 3 November 2020) and the $\mathrm{CO}_{2}$ Human Emissions (CHE) project (https://www.che-project.eu/, last access: 3 November 2020). As an example of successful implementation of the top-down approach, one can mention the experience of the United Kingdom in the evaluation of greenhouse gas emission national inventory (Stanley et al., 2018; WMO Greenhouse Gas Bulletin, 2018). Disaggregation of national $\mathrm{FF} \mathrm{CO}_{2}$ emission estimates provided the possibility to compile ODIAC (Open-Data Inventory for Anthropogenic $\mathrm{CO}_{2}$ ) which is a high-resolution global open database of anthropogenic $\mathrm{CO}_{2}$ emissions (Oda and Maksyutov, 2011; Oda et al., 2018).

Recently, much attention has been paid to the improvement of the estimates of the $\mathrm{CO}_{2}$ emissions by the world's largest megacities (Mays et al., 2009; Wunch et al., 2009; Bergeron and Strachan, 2011; Levin et al., 2011; Silva et al., 2013; Hase et al., 2015; Vogel et al., 2019; Babenhauserheide et al., 2020). A lot of studies are based on the results of routine observations by the international ground-based monitoring networks such as ICOS (Integrated Carbon Observation System; ICOS, 2020), NOAA ESRL (National Oceanic and Atmospheric Administration Earth System Research Laboratory; NOAA ESRL, 2020), TCCON (Total Carbon Column Observing Network; TCCON, 2021), COCCON (Collaborative Carbon Column Observing Network; COCCON, 2021) and FLUXNET (FLUXNET, 2020). Also, national instrumental air quality control systems were used (Airparif, 2020) together with satellite measurement systems (Kuhlmann et al., 2019; Oda et al., 2018) and individual observational stations (Zinchenko et al., 2002; Pillai et al., 2011). It is important to mention measurement campaigns organized in the framework of major scientific projects, such as InFLUX (In- dianapolis Flux Experiment; http://sites.psu.edu/influx, last access: 3 November 2020; Turnbull et al., 2014), the Megacities Carbon Project (https://megacities.jpl.nasa.gov/portal/, last access: 3 November 2020; Duren and Miller, 2012), MEGAPOLI (MEGAcities: Emissions, urban, regional and Global Atmospheric POLlution and climate effects, and Integrated tools for assessment and mitigation; http://www. megapoli.info, last access: 3 November 2020, Lopez et al., 2013), the $\mathrm{CO}_{2}$-MEGAPARIS project in Paris, France (https://co2-megaparis.1sce.ipsl.fr, last access: 3 November 2020, Bréon et al., 2015), COCCON in Paris (http: //www.chasing-greenhouse-gases.org/coccon-in-paris/, last access: 3 November 2020) and VERIFY (https://verify.lsce. ipsl.fr/, last access: 3 November 2020). The important goal is to improve existing techniques and to develop new algorithms for the space-borne detection of the $\mathrm{CO}_{2}$ plumes originating from intensive compact sources such as large cities and big thermal power plants (TPPs; Kuhlmann et al., 2019; SMARTCARB project, https://www.empa.ch/web/ s503/smartcarb, last access: 3 November 2020). Bovensmann et al. (2010) and Pillai et al. (2016) proposed creating and launching new specialized satellite instruments to study natural and anthropogenic sources and sinks of carbon dioxide with high spatial resolution. At the same time, the variety of modelling tools used to simulate the atmospheric $\mathrm{CO}_{2}$ fields and assimilate the results of observations is also quite large, ranging from simple mass balance models (Hiller et al., 2014; Zimnoch et al., 2010; Makarova et al., 2018) to modern transport and photochemical models (Ahmadov et al., 2009; Göckede et al., 2010; Pillai et al., 2011, 2012).

The present study is focused on the $\mathrm{CO}_{2}$ emission by $\mathrm{St}$ Petersburg, Russian Federation. The area of the St Petersburg urban agglomeration is about $1440 \mathrm{~km}^{2}$, while the city centre, which is characterized by high construction density, occupies $650 \mathrm{~km}^{2}$. The city has a population of $\sim 5.4$ million people (the official data for 2019, St Petersburg Centre for Information and Analytics, 2020); according to unofficial data, the population is now more than 7 million (Shevlyagina, 2021). The population density is $\sim 3800$ people $\mathrm{km}^{-2}$ on average. It can reach $\sim 7300$ people $\mathrm{km}^{-2}$ in the territories with high construction density (Solodilov, 2005). The data on total emissions of anthropogenic air pollutants in St Petersburg are provided in the annual reports of the municipal Environmental Committee (Serebritsky, 2018, 2019). Published data are based on the emission sources inventory method (bottomup) where $\mathrm{CO}_{2}$ fluxes for urban areas are calculated on the basis of information about the landscape and the type of anthropogenic activity (e.g. number and type of buildings, location of roads, traffic intensity, the presence and type of TPP, etc.) using appropriate emission factors (Gurney et al., 2002; Serebritsky, 2018). On average, the contribution of St Petersburg to the total greenhouse gas emissions of the Russian Federation is about $1 \%$. According to official inventory data for 2015, the integral $\mathrm{CO}_{2}$ emission from the territory of St Petersburg is about $30 \mathrm{Mtyr}^{-1}$, and the interannual variabil- 
ity of this estimate in the period 2011-2015 did not exceed $1 \mathrm{Mt} \mathrm{yr}^{-1}$ (Serebritsky, 2018). In the mentioned official inventory report, it is noted that most of St Petersburg's emissions (more than $90 \%$ ) are associated with power production. These estimates differ, for example, from the results obtained in the study of the structure of anthropogenic $\mathrm{CO}_{2}$ emissions by the city of Baltimore (Maryland, USA). Roest et al. (2020) reported that electricity production in Baltimore emits only $9 \%$ of $\mathrm{CO}_{2}$, and the main part of emissions is related to transport (automobile $34 \%$, marine $4 \%$ and air and rail transport $2 \%)$ and to the commercial sector $(20 \%)$, industry (19\%) and private residential housing (12\%).

The main anthropogenic source of $\mathrm{CO}_{2}$ is associated with the consumption of fossil fuels. However, a number of studies have demonstrated that, for the territories with high population density, carbon dioxide produced by the human respiration process can make a significant contribution to total emissions (Bréon et al., 2015; Ciais et al., 2007; Widory and Javoy, 2003). According to some estimates, by breathing, one person emits, on average, $1 \mathrm{~kg}$ of $\mathrm{CO}_{2}$ per day (Prairie and Duarte, 2007), which would amount to about $3 \mathrm{Mt}$ of $\mathrm{CO}_{2}$ per year for St Petersburg. Bréon et al. (2015) have shown that for Paris the $\mathrm{CO}_{2}$ emission from human breathing constitutes $8 \%$ of the total inventory emissions of the metropolis due to the use of fossil fuels.

Official inventory (bottom-up) estimates of the $\mathrm{CO}_{2}$ emissions for St Petersburg (Serebritsky, 2018) may have significant uncertainties both in the estimates of integral emissions and in the data on the spatial and temporal distribution of the $\mathrm{CO}_{2}$ fluxes. This suggestion is confirmed, in particular, by the significantly different values of the CO-to- $\mathrm{CO}_{2}$ emission ratio (ER) for St Petersburg obtained by Makarova et al. (2021) from the field measurements $\left(\mathrm{ER}_{\mathrm{CO} / \mathrm{CO}_{2}} \approx\right.$ 6 ppbv ppmv $^{-1}$, where ppbv is parts per billion by volume) and calculated using the official emission inventory data reported by Serebritsky (2018; $\mathrm{ER}_{\mathrm{CO} / \mathrm{CO}_{2}} \approx 21 \mathrm{ppbv} \mathrm{ppmv}^{-1}$ ). The $\mathrm{ER}_{\mathrm{CO} / \mathrm{CO}_{2}}$ ratio is one of the most important characteristics of the source of air pollution, since its value can indicate the nature of the emission. For cities, $\mathrm{ER}_{\mathrm{CO} / \mathrm{CO}_{2}}$ mostly reflects the structure of FF consumption.

In 2019, the mobile experiment EMME (Emission Monitoring Mobile Experiment) was carried out on the territory of the St Petersburg agglomeration with the aim of estimating the emission intensity of greenhouse $\left(\mathrm{CO}_{2}\right.$ and $\left.\mathrm{CH}_{4}\right)$ and reactive $\left(\mathrm{CO}\right.$ and $\mathrm{NO}_{x}$ ) gases for St Petersburg (Makarova et al., 2021). St Petersburg State University (Russia), the Karlsruhe Institute of Technology (Germany) and the University of Bremen (Germany) jointly prepared and conducted this city campaign. The core instruments of the campaign were two portable FTIR (Fourier Transform InfraRed) spectrometers (Bruker EM27/SUN) which were used for ground-based remote sensing measurements of the total column amount of $\mathrm{CO}_{2}, \mathrm{CH}_{4}$ and $\mathrm{CO}$ at upwind and downwind locations on opposite sides of the city. The applicability and efficiency of this measurement scenario and EM27/SUN spectrometers have been shown by Hase et al. (2015), Chen et al. (2016) and Dietrich et al. (2021). The description of the EMME experiment has been given in full detail in the paper by Makarova et al. (2021). This study has also reported the estimations of the area fluxes for the emissions of $\mathrm{CO}_{2}, \mathrm{CH}_{4}, \mathrm{NO}_{x}$ and $\mathrm{CO}$ by St Petersburg. In 2020, the EMME experiment was continued. It started in March before the COVID-19 pandemic lockdown and consisted of $6 \mathrm{~d}$ of field measurements $(3 \mathrm{~d}$ before the lockdown and $3 \mathrm{~d}$ during the lockdown).

The present study continues the analysis of the data of EMME-2019 and demonstrates the first results of the 2020 campaign. We concentrate our efforts on the $\mathrm{CO}_{2}$ emissions and leave the results relevant to other gases beyond the scope of the research. As an extension of the work by Makarova et al. (2021), our goal in this paper is to estimate the integral $\mathrm{CO}_{2}$ emission by St Petersburg megacity rather than area fluxes. Completing this task consists of the following basic steps:

- We use mobile FTIR measurements to obtain $\mathrm{CO}_{2}$ column enhancements $\left(\Delta \mathrm{CO}_{2}\right)$ related to urban anthropogenic emissions.

- We adapt the ODIAC database (Oda and Maksyutov, 2011) to construct a priori information on the spatiotemporal distribution of anthropogenic $\mathrm{CO}_{2}$ emissions on the territory of St Petersburg.

- We initialize the HYSPLIT dispersion model, HYbrid Single-Particle Lagrangian Integrated Trajectories (Draxler and Hess, 1998; Stein et al., 2015), with the ODIAC emissions to simulate $\mathrm{CO}_{2} 3 \mathrm{D}$ field over the city of St Petersburg.

- We evaluate the performance of our HYSPLIT model set-up by calculating the surface $\mathrm{CO}_{2}$ concentrations and comparing them with the routine in situ measurement results (Foka et al., 2019).

- We scale the emission input data for the HYSPLIT model simulations in order to reproduce the observed $\Delta \mathrm{CO}_{2}$.

- Finally, we obtain the estimate of integral $\mathrm{CO}_{2}$ emission by St Petersburg from the scaled emission a priori data.

The paper is organized as follows. Section 2 describes the methods and instruments, including a description of the EMME measurement campaign and the equipment used, methods for processing the measurement results, the configuration of the HYSPLIT model and its evaluation based on calculations of ground-level $\mathrm{CO}_{2}$ concentrations. Section 3 presents main results of EMME-2019 and EMME-2020, including estimates of integrated $\mathrm{CO}_{2}$ emissions derived from FTIR measurements of the 2019 and 2020 field campaigns, combined with HYSPLIT model simulations. Section 4 contains a summary of our findings. 


\section{Methods and instrumentation}

The main goal of the EMME measurement campaigns in 2019 and 2020 organized jointly by SPbU (St Petersburg State University, Russia), KIT (Karlsruhe Institute of Technology, Germany) and UoB (University of Bremen, Germany) was to evaluate emissions of $\mathrm{CO}_{2}, \mathrm{CH}_{4}, \mathrm{CO}$ and $\mathrm{NO}_{x}$ from the territory of St Petersburg. Similar to 2019, the EMME-2020 campaign was conducted in spring (Marchearly May). This time of the year is preferable for a successful study of urban emissions, especially $\mathrm{CO}_{2}$, due to the following reasons: (1) a daylight duration is sufficient for FTIR remote sensing measurements, (2) the influence of vegetation processes on the daily evolution of the $\mathrm{CO}_{2}$ concentration in the atmosphere is negligible and (3) the winter heating of the city buildings is still active, which is a significant source of the $\mathrm{CO}_{2}$ emissions for northern cities such as St Petersburg. In contrast to the 2019 campaign, when two mobile (Bruker EM27/SUN) FTIR spectrometers were used in the field experiment for simultaneous measurements inside and outside of the air pollution plume, all measurements in 2020 were performed with one spectrometer which was moved between clean and polluted locations within $1 \mathrm{~d}$. In 2019, the field measurements were carried out during $11 \mathrm{~d}$ in total and on $6 \mathrm{~d}$ in 2020. The number of observations in 2020 was smaller than in 2019 due to the quarantine restrictions related to the COVID-19 pandemic. These restrictions were imposed in St Petersburg on 28 March 2020. During several days of the 2020 campaign, measurements inside the city pollution plume were made at two locations, which allowed us to increase the total number of observations. Details of both field campaigns are given in Tables 1 and 2 for 2019 and 2020, respectively. The tables contain the Fourier transform spectrometer (FTS) instrument IDs (nos. 80 and 84 in 2019 and no. 84 in 2020), the position on the upwind and downwind sides of the city (latitude and longitude) and the duration of observations. Note that each experiment presented in the tables consists of a pair of series of measurements - from the upwind and downwind sides. In 2019, simultaneous observations of two FTS instruments (nos. 80 and 84) were used for this purpose (see Table 1). In 2020, the single FTS instrument (no. 84) was moved between the upwind and downwind positions (see Table 2). The average duration of measurements in 2019 was $3 \mathrm{~h}$ within the period of $\sim 12: 00-15: 00$ local time (LT; unless otherwise indicated, hereafter all times are given in LT). In 2020, the duration of the measurements was limited to about $1 \mathrm{~h}$ (sometimes less), and the observation time varied from 11:00 to 19:00. Since a single instrument was used in 2020, the time difference between upwind and downwind measurements in 2020 ranged from 3 to $5 \mathrm{~h}$.

\subsection{Bruker EM27/SUN FTS and spectra processing}

The Bruker EM27/SUN (Gisi et al., 2012; Frey et al., 2015; Hase et al., 2016) is a portable, robust FTS with a low spec- tral resolution of $0.5 \mathrm{~cm}^{-1}$. It was designed for accurate and precise ground-based observations of $\mathrm{CO}_{2}, \mathrm{CH}_{4}$ and $\mathrm{CO}$ column-averaged abundances $\left(X_{\mathrm{CO}_{2}}, X_{\mathrm{CH}_{4}}\right.$ and $\left.X_{\mathrm{CO}}\right)$ in the atmosphere. These FTIR spectrometers were used to build the COCCON network (COCCON, 2021; Frey et al., 2019). The EM27/SUN is equipped with a Camtracker, a solar tracking system developed by KIT (Gisi et al., 2011). The Camtracker consists of an altazimuthal solar tracker, a USB digital camera and CamTrack software which processes an image acquired by a camera and controls the tracker's movement. The EM27/SUN FTS is designed on the basis of a robust RockSolid ${ }^{\mathrm{TM}}$ interferometer with high thermal and vibrational stability; the detailed description of the instrument is given by Gisi et al. (2012). Therefore, this type of instruments is being successfully implemented for setting up fully automated stationary city network MUCCnet (Munich Urban Carbon Column network; Dietrich et al., 2021) and for performing a number of mobile campaigns (Klappenbach et al., 2015; Luther et al., 2019; Makarova et al., 2021).

In our study, we used the dual-channel EM27/SUN with a quartz beam splitter. Additionally, two detectors allow the observation of $X_{\mathrm{CO}}$ and future improvements of the $X_{\mathrm{CO}_{2}}$ retrieval (Hase et al., 2016). FTS registers an interferogram which is the Fourier transform of the infrared spectrum of direct solar radiation. The processing of data acquired by the EM27/SUN spectrometer consists of the following stages:

- deriving spectra from raw interferograms, including a direct current (DC) correction and quality assurance procedures (Keppel-Aleks et al., 2007), and

- deriving $\mathrm{O}_{2}, \mathrm{CO}_{2}, \mathrm{CO}, \mathrm{H}_{2} \mathrm{O}$ and $\mathrm{CH}_{4}$ total columns (TCs) from FTIR spectra by scaling a priori profiles of retrieved gases (Frey et al., 2019; COCCON, 2021).

To process the spectral data, we used the free software, PROFFAST, which had been specially developed for COCCON network (COCCON, 2021; Frey et al., 2019). PROFFAST was developed by KIT in the framework of several ESA projects for processing the raw data delivered by the EM27/SUN FTS. For the retrievals of TCs of target species, the following spectral bands are used (Frey et al., 2015; Hase et al., 2016; Frey et al., 2019): $4210-4320 \mathrm{~cm}^{-1}$ (target gas - $\mathrm{CO}$; interfering gases $-\mathrm{H}_{2} \mathrm{O}$, $\mathrm{HDO}$ and $\mathrm{CH}_{4}$ ), $5897-6145 \mathrm{~cm}^{-1}$ (target gas $-\mathrm{CH}_{4}$; interfering gases $-\mathrm{H}_{2} \mathrm{O}$, $\mathrm{HDO}$ and $\mathrm{CO}_{2}$ ), 6173-6390 $\mathrm{cm}^{-1}$ (target gas $-\mathrm{CO}_{2}$; interfering gases $-\mathrm{H}_{2} \mathrm{O}$, HDO and $\mathrm{CH}_{4}$ ), $7765-8005 \mathrm{~cm}^{-1}$ (target gas $-\mathrm{O}_{2}$; interfering gases $-\mathrm{H}_{2} \mathrm{O}$, $\mathrm{HF}$ and $\mathrm{CO}_{2}$ ) and $8353-8463 \mathrm{~cm}^{-1}$ (target gas $-\mathrm{H}_{2} \mathrm{O}$ ). The retrieval algorithm requires the following input: a temperature profile in the atmosphere, pressure at the ground level, and the a priori data on the mole fraction vertical distribution of the atmospheric trace gases. These data are generated by the TCCON network software, which ensures their compatibility over the TCCON network (TCCON, 2021). The close agreement of EM27/SUN observations analysed with PROFFAST with a 
Table 1. The EMME-2019 field campaign details, including the dates of experiments in 2019 and the locations of FTS instruments during the upwind and downwind observations. The data on the direction and speed of the surface wind correspond to observations at one of the meteorological stations in the centre of St Petersburg at local noon (http://rp5.ru/Weather_archive_in_Saint_Petersburg, last access: 11 March 2021).

\begin{tabular}{|c|c|c|c|c|c|}
\hline \multirow[t]{2}{*}{ No. } & \multirow[t]{2}{*}{ Date } & \multirow[t]{2}{*}{$\begin{array}{r}\text { Wind speed } \\
\left(\mathrm{m} \mathrm{s}^{-1}\right)\end{array}$} & \multirow[t]{2}{*}{$\begin{array}{l}\text { Wind } \\
\text { direction }\end{array}$} & \multicolumn{2}{|c|}{$\begin{array}{l}\text { FTS identifier (instrument no.), } \\
\text { location (latitude and longitude) } \\
\text { and observation time (local) }\end{array}$} \\
\hline & & & & Upwind & Downwind \\
\hline 1. & 21 March 2019 & 3 & WSW & $\begin{array}{l}\text { No. } 80 \\
59.88^{\circ} \mathrm{N}, 29.83^{\circ} \mathrm{E} \\
14: 07-15: 07\end{array}$ & $\begin{array}{l}\text { No. } 84 \\
59.95^{\circ} \mathrm{N}, 30.59^{\circ} \mathrm{E} \\
13: 08-15: 36\end{array}$ \\
\hline 2. & 27 March 2019 & 2 & WSW & $\begin{array}{l}\text { No. } 84 \\
60.01^{\circ} \mathrm{N}, 29.69^{\circ} \mathrm{E} \\
11: 49-15: 08\end{array}$ & $\begin{array}{l}\text { No. } 80 \\
59.85^{\circ} \mathrm{N}, 30.54^{\circ} \mathrm{E} \\
11: 42-14: 57\end{array}$ \\
\hline 3. & 1 April 2019 & 3 & WSW & $\begin{array}{l}\text { No. } 84 \\
60.01^{\circ} \mathrm{N}, 29.69^{\circ} \mathrm{E} \\
11: 01-13: 24\end{array}$ & $\begin{array}{l}\text { No. } 80 \\
59.85^{\circ} \mathrm{N}, 30.54^{\circ} \mathrm{E} \\
11: 15-14: 31\end{array}$ \\
\hline 4. & 3 April 2019 & 3 & $\mathrm{~S}$ & $\begin{array}{l}\text { No. } 84 \\
59.88^{\circ} \mathrm{N}, 29.83^{\circ} \mathrm{E} \\
14: 47-16: 02\end{array}$ & $\begin{array}{l}\text { No. } 80 \\
60.04^{\circ} \mathrm{N}, 30.47^{\circ} \mathrm{E} \\
11: 57-14: 21\end{array}$ \\
\hline 5. & 4 April 2019 & 3 & SW & $\begin{array}{l}\text { No. } 84 \\
59.81^{\circ} \mathrm{N}, 30.09^{\circ} \mathrm{E} \\
11: 59-14: 16\end{array}$ & $\begin{array}{l}\text { No. } 80 \\
60.04^{\circ} \mathrm{N}, 30.47^{\circ} \mathrm{E} \\
11: 59-14: 16\end{array}$ \\
\hline 6. & 6 April 2019 & 2 & SE & $\begin{array}{l}\text { No. } 84 \\
59.95^{\circ} \mathrm{N}, 30.59^{\circ} \mathrm{E} \\
12: 14-15: 23\end{array}$ & $\begin{array}{l}\text { No. } 80 \\
60.01^{\circ} \mathrm{N}, 29.69^{\circ} \mathrm{E} \\
12: 15-15: 29\end{array}$ \\
\hline 7. & 16 April 2019 & 2 & $\mathrm{NE}$ & $\begin{array}{l}\text { No. } 84 \\
60.01^{\circ} \mathrm{N}, 29.69^{\circ} \mathrm{E} \\
11: 13-15: 08\end{array}$ & $\begin{array}{l}\text { No. } 80 \\
59.86^{\circ} \mathrm{N}, 30.11^{\circ} \mathrm{E} \\
11: 21-14: 59\end{array}$ \\
\hline 8. & 18 April 2019 & 2 & $\mathrm{NE}$ & $\begin{array}{l}\text { No. } 80 \\
60.04^{\circ} \mathrm{N}, 30.47^{\circ} \mathrm{E} \\
12: 07-14: 56\end{array}$ & $\begin{array}{l}\text { No. } 84 \\
59.81^{\circ} \mathrm{N}, 30.09^{\circ} \mathrm{E} \\
11: 38-15: 24\end{array}$ \\
\hline 9. & 24 April 2019 & 1 & WSW & $\begin{array}{l}\text { No. } 84 \\
60.01^{\circ} \mathrm{N}, 29.69^{\circ} \mathrm{E} \\
11: 38-14: 55\end{array}$ & $\begin{array}{l}\text { No. } 80 \\
59.85^{\circ} \mathrm{N}, 30.54^{\circ} \mathrm{E} \\
11: 52-15: 22\end{array}$ \\
\hline 10. & 25 April 2019 & 1 & WSW & $\begin{array}{l}\text { No. } 80 \\
60.04^{\circ} \mathrm{N}, 30.47^{\circ} \mathrm{E} \\
12: 07-14: 49\end{array}$ & $\begin{array}{l}\text { No. } 84 \\
59.81^{\circ} \mathrm{N}, 30.09^{\circ} \mathrm{E} \\
11: 19-15: 08\end{array}$ \\
\hline 11. & 30 April 2019 & 2 & SSE & $\begin{array}{l}\text { No. } 80 \\
59.85^{\circ} \mathrm{N}, 30.54^{\circ} \mathrm{E} \\
12: 35-13: 31\end{array}$ & $\begin{array}{l}\text { No. } 84 \\
60.01^{\circ} \mathrm{N}, 29.69^{\circ} \mathrm{E} \\
12: 22-13: 46\end{array}$ \\
\hline
\end{tabular}

collocated TCCON spectrometer has been demonstrated in the framework of the ESA project FRM4GHG (Sha, 2020).

In order to obtain a reliable value of the $\mathrm{CO}_{2}$ emission for St Petersburg, it is necessary to eliminate possible systematic error caused by the instrument bias. This goal was reached by carrying out a cross-calibration of the instruments. In AprilMay 2019, both instruments passed a $4 \mathrm{~d}$ cross-calibration.
The comparison of side-by-side measurements of $X_{\mathrm{CO}_{2}}$ by FTS nos. 80 and 84 allowed us to determine the calibration factor which was used for converting $X_{\mathrm{CO}_{2}}$ measured by FTS no. 80 to the scale of FTS no. 84. Detailed information about the side-by-side calibration of FTIR-spectrometers is given in the paper by Makarova et al. (2021). 
Table 2. The EMME-2020 field campaign details, including the dates of the experiments in 2020 and the locations of FTS instrument during the upwind and downwind observations. The data on the direction and speed of the surface wind correspond to observations at one of the meteorological stations in the centre of St Petersburg at local noon (http://rp5.ru/Weather_archive_in_Saint_Petersburg, last access: 11 March 2021).

\begin{tabular}{|c|c|c|c|c|c|}
\hline \multirow[t]{2}{*}{ No. } & \multirow[t]{2}{*}{ Date } & \multirow[t]{2}{*}{$\begin{array}{r}\text { Wind speed } \\
\left(\mathrm{m} \mathrm{s}^{-1}\right)\end{array}$} & \multirow[t]{2}{*}{$\begin{array}{l}\text { Wind } \\
\text { direction }\end{array}$} & \multicolumn{2}{|c|}{$\begin{array}{l}\text { FTS identifier (instrument no.), } \\
\text { location (latitude and longitude) } \\
\text { and observation time (local) }\end{array}$} \\
\hline & & & & Upwind & Downwind \\
\hline 1. & 22 March 2020 & 1 & $\mathrm{~N}$ & $\begin{array}{l}\text { No. } 84 \\
60.11^{\circ} \mathrm{N}, 30.48^{\circ} \mathrm{E} \\
10: 38-11: 55\end{array}$ & $\begin{array}{l}\text { No. } 84 \\
59.94^{\circ} \mathrm{N}, 30.40^{\circ} \mathrm{E} \\
13: 17-14: 38\end{array}$ \\
\hline 2. & 22 March 2020 & 1 & $\mathrm{~N}$ & $\begin{array}{l}\text { No. } 84 \\
60.11^{\circ} \mathrm{N}, 30.48^{\circ} \mathrm{E} \\
10: 38-11: 55\end{array}$ & $\begin{array}{l}\text { No. } 84 \\
59.81^{\circ} \mathrm{N}, 30.14^{\circ} \mathrm{E} \\
15: 55-17: 16\end{array}$ \\
\hline 3. & 23 March 2020 & 2 & $\mathrm{~W}$ & $\begin{array}{l}\text { No. } 84 \\
59.93^{\circ} \mathrm{N}, 29.64^{\circ} \mathrm{E} \\
12: 55-14: 33\end{array}$ & $\begin{array}{l}\text { No. } 84 \\
59.90^{\circ} \mathrm{N}, 30.52^{\circ} \mathrm{E} \\
16: 24-18: 02\end{array}$ \\
\hline 4. & 27 March 2020 & 2 & WSW & $\begin{array}{l}\text { No. } 84 \\
59.88^{\circ} \mathrm{N}, 29.83^{\circ} \mathrm{E} \\
10: 35-11: 51\end{array}$ & $\begin{array}{l}\text { No. } 84 \\
59.94^{\circ} \mathrm{N}, 30.60^{\circ} \mathrm{E} \\
13: 24-14: 12\end{array}$ \\
\hline 5. & 27 March 2020 & 2 & WSW & $\begin{array}{l}\text { No. } 84 \\
59.88^{\circ} \mathrm{N}, 29.83^{\circ} \mathrm{E} \\
10: 35-11: 51\end{array}$ & $\begin{array}{l}\text { No. } 84 \\
59.96^{\circ} \mathrm{N}, 30.60^{\circ} \mathrm{E} \\
14: 34-15: 15\end{array}$ \\
\hline 6. & 5 April 2020 & 4 & WSW & $\begin{array}{l}\text { No. } 84 \\
59.82^{\circ} \mathrm{N}, 29.96^{\circ} \mathrm{E} \\
12: 44-13: 43\end{array}$ & $\begin{array}{l}\text { No. } 84 \\
59.83^{\circ} \mathrm{N}, 30.52^{\circ} \mathrm{E} \\
10: 53-11: 48\end{array}$ \\
\hline 7. & 8 April 2020 & 3 & WSW & $\begin{array}{l}\text { No. } 84 \\
59.89^{\circ} \mathrm{N}, 29.89^{\circ} \mathrm{E} \\
14: 58-16: 46\end{array}$ & $\begin{array}{l}\text { No. } 84 \\
59.83^{\circ} \mathrm{N}, 30.52^{\circ} \mathrm{E} \\
11: 09-13: 43\end{array}$ \\
\hline 8. & 1 May 2020 & 1 & ESE & $\begin{array}{l}\text { No. } 84 \\
59.73^{\circ} \mathrm{N}, 30.25^{\circ} \mathrm{E} \\
18: 01-19: 03\end{array}$ & $\begin{array}{l}\text { No. } 84 \\
60.05^{\circ} \mathrm{N}, 30.06^{\circ} \mathrm{E} \\
13: 22-14: 27\end{array}$ \\
\hline 9. & 1 May 2020 & 1 & ESE & $\begin{array}{l}\text { No. } 84 \\
59.73^{\circ} \mathrm{N}, 30.25^{\circ} \mathrm{E} \\
\text { 18:01-19:03 }\end{array}$ & $\begin{array}{l}\text { No. } 84 \\
60.03^{\circ} \mathrm{N}, 30.00^{\circ} \mathrm{E} \\
15: 10-16: 11\end{array}$ \\
\hline
\end{tabular}

\subsection{A priori data on $\mathrm{FF} \mathrm{CO}_{2}$ emissions}

The global emission inventory ODIAC (Oda and Maksyutov, 2011; Oda et al., 2018) is used in the present study for a characterization of the area fluxes of the $\mathrm{CO}_{2}$ emission from the territory of St Petersburg and its suburbs. ODIAC provides global information on monthly average $\mathrm{CO}_{2}$ emissions due to consumption of fossil fuels. The high spatial resolution of ODIAC $(1 \mathrm{~km} \times 1 \mathrm{~km})$ is achieved through a joint interpretation of the existing global inventory of anthropogenic $\mathrm{CO}_{2}$ sources, data on FF consumption and satellite observations of the nighttime glow of densely populated areas of the Earth. We use the data for 2018 emissions given in the ODIAC2019 version (Oda and Maksyutov, 2020).
The $\mathrm{CO}_{2}$ emission data have been extracted from the ODIAC database for the domain that includes St Petersburg and its suburbs $\left(59.60-60.29^{\circ} \mathrm{N}, 29.05-31.33^{\circ} \mathrm{E}\right.$; Fig. 1). The sources of anthropogenic $\mathrm{CO}_{2}$ emissions are concentrated within the administrative borders of the city. Most of these sources have intensities of $\sim 4000 \mathrm{t}$ per month per square kilometre and higher and are located within the borders of the city ring road. Summing up the ODIAC data within the city borders gives an estimate of the average integrated $\mathrm{CO}_{2}$ emission of $\sim 2710 \mathrm{kt}$ per month, with variations from $2429 \mathrm{kt}$ in July to $3119 \mathrm{kt}$ in March (Fig. 2). The emissions are maximal in late winter and early spring and are minimal in summer. In general, the seasonal variability in emissions is insignificant $(\sim 8 \%)$; therefore the data for 


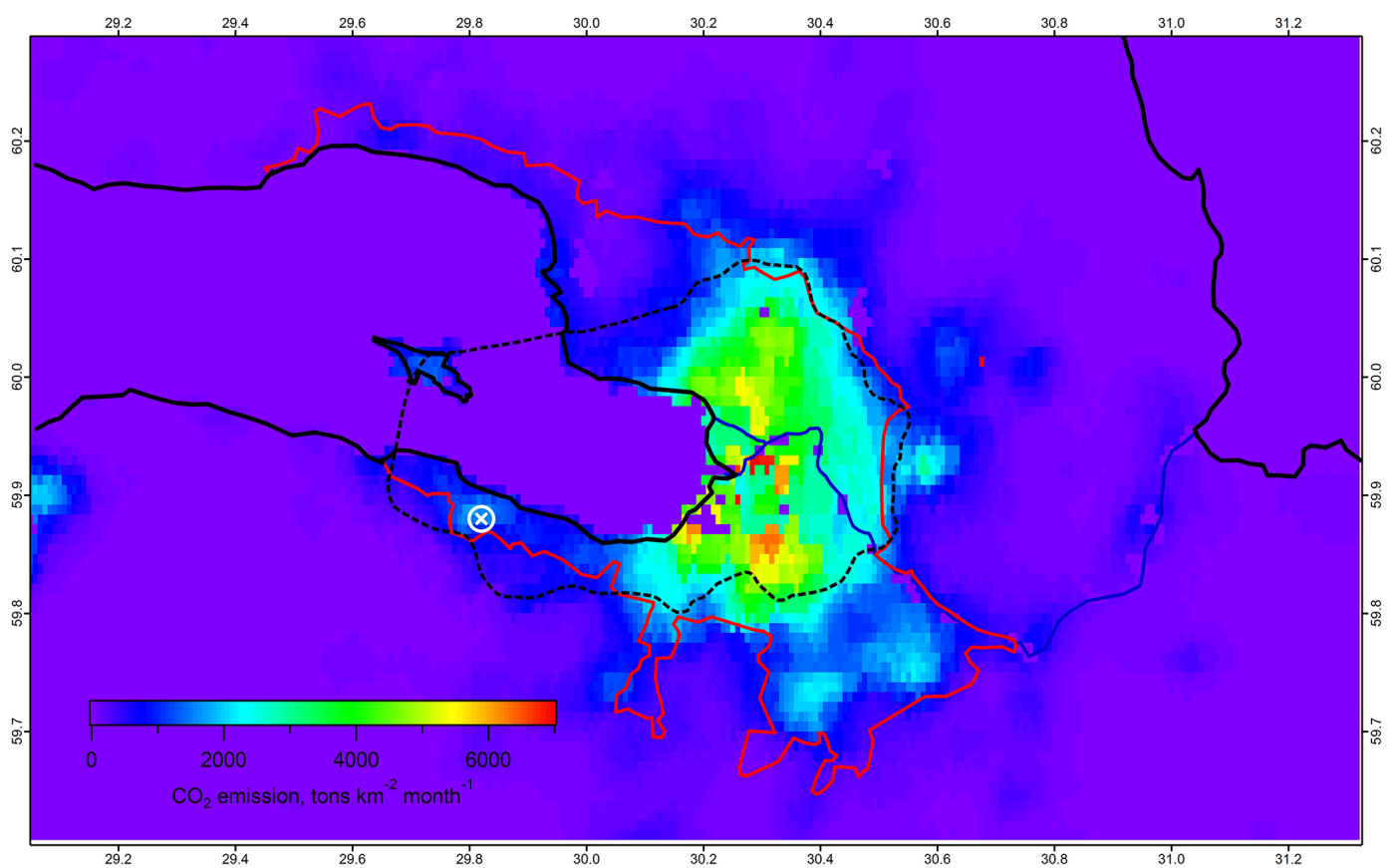

Figure 1. Spatial distribution of anthropogenic $\mathrm{CO}_{2}$ emission intensity on the territory of the St Petersburg agglomeration (59.60-60.29 ${ }^{\circ}$, 29.05-31.33 ${ }^{\circ}$ E) according to ODIAC2019 data for April 2018. The red line indicates the administrative border of the city; the black dotted line indicates the city ring road. A white circle depicts the location of the atmospheric monitoring station of St Petersburg University in Peterhof (see the text).

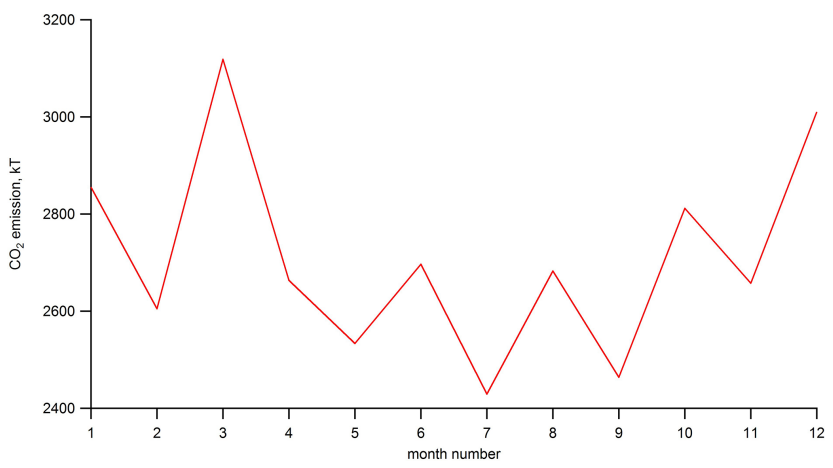

Figure 2. Integrated monthly mean $\mathrm{FF} \mathrm{CO}_{2}$ emission from the territory of St Petersburg, according to ODIAC2019 data in 2018.

12 months of 2018 were averaged in order to obtain an estimate of the mean annual distribution of urban $\mathrm{CO}_{2}$ emissions. The integrated annual emission of St Petersburg equals $32529 \mathrm{kt}$, which is in good agreement with published official estimates, i.e. about 30 million t for the period from 2011 to 2015 (Serebritsky, 2018).

The nominal latitude/longitude size of the ODIAC data pixel is 30 arcsec (Oda and Maksyutov, 2011), which defines a global spatial resolution of about $1 \mathrm{~km} \times 1 \mathrm{~km}$. Since the length of a degree of longitude changes with the latitude, the pixel size for St Petersburg $\left(\sim 60^{\circ} \mathrm{N}\right)$ is smaller and equals to $0.93 \mathrm{~km} \times 0.46 \mathrm{~km}\left(0.43 \mathrm{~km}^{2}\right)$. It should be noted that the average annual urban emission flux is $\sim 26 \mathrm{kt} \mathrm{km}^{-2}$, while in the central part of the city it can reach up to $80 \mathrm{kt} \mathrm{km}^{-2}$. There is one pixel in the ODIAC data located in the centre of St Petersburg with an extremely high emission flux of $7000 \mathrm{kt} \mathrm{km}^{-2}$. Normally, power plants and industrial enterprises manifest themselves as point sources of strong emission. However, we cannot confidently attribute this particular ODIAC pixel to any source of this type since there is no such object near it. There are about a dozen of large thermal power plants in the territory of St Petersburg, but all of them appear to be rather far from this location. Despite the lack of published data on anthropogenic $\mathrm{CO}_{2}$ emissions at the city scale, we were able to explore detailed reports from municipal inventories of stationary air pollution sources (unpublished but available on request). According to the inventories of $\mathrm{NO}_{x}$, $\mathrm{CO}, \mathrm{SO}_{2}, \mathrm{NH}_{3}, \mathrm{VOC}$ (volatile organic carbon) and $\mathrm{PM}_{10}$ pollutants, there are no stationary objects of an extreme emission close to the point of our interest. Thus, we feel confident in smoothing out this outlier and replacing it by the value averaged over the neighbouring ODIAC pixels. As a result, it amounted to $42 \mathrm{kt} \mathrm{km}^{-2}$.

\subsection{The HYSPLIT model general set-up}

The spatial and temporal evolution of the urban pollution plume was simulated using the HYSPLIT model (Draxler and Hess, 1998; Stein et al., 2015). Calculations were performed for the territory of the St Petersburg agglomeration 

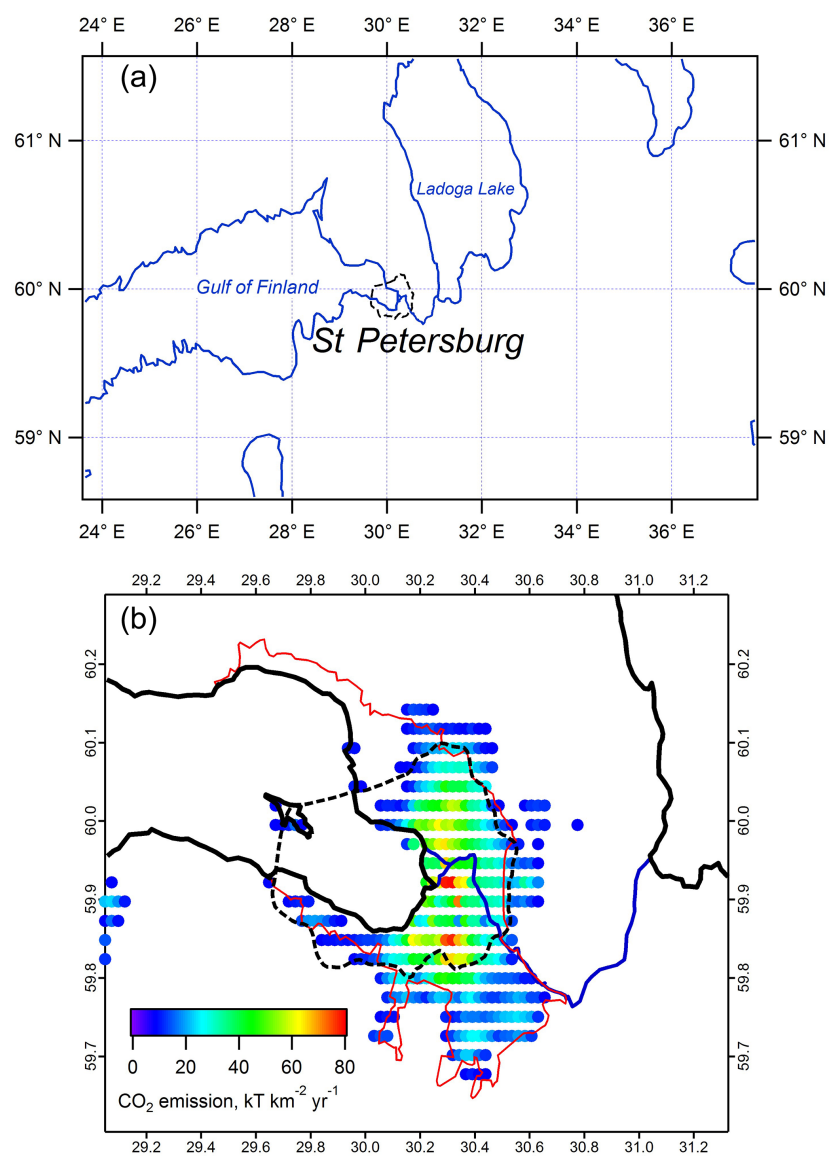

Figure 3. (a) Map of the spatial domain specified in the HYSPLIT model configuration in the city of St Petersburg and the surrounding area. (b) The pixel map of the $\mathrm{CO}_{2}$ emissions generated using ODIAC2019.

using the offline version of the HYSPLIT model, with the set-up similar to the one that was successfully used previously for the $\mathrm{NO}_{x}$ plume modelling (Ionov and Poberovskii, 2019; Makarova et al., 2021). A 3D field of anthropogenic air pollution was calculated for a spatial domain with the coordinates $54.8-61.6^{\circ} \mathrm{N}, 23.7-37.8^{\circ} \mathrm{E}$; the domain grid size was $0.05^{\circ} \times 0.05^{\circ}$ latitude and longitude (see Fig. 3, top). The vertical grid of the model is set to 10 layers, with the altitude of the upper level at 1, 25, 50, 100, 150, 250, 350, 500, 1000 and $1500 \mathrm{~m}$ a.s.l., respectively. As a source of meteorological information (vertical profiles of the horizontal and vertical wind components, temperature and pressure profiles, etc.), the NCEP GDAS (National Centers for Environmental Prediction Global Forecast System) data were used and presented on a global spatial grid of $0.5^{\circ} \times 0.5^{\circ}$ latitude and longitude with a time interval of $3 \mathrm{~h}$ (NCEP GDAS, 2020).

To run HYSPLIT, we used the software package HYSPLIT 4 (June 2015 release; subversion 761). The advanced set-up of the HYSPLIT model was configured as follows (basic parameters):
- default method of vertical turbulence computation

- horizontal mixing computed proportional to vertical mixing

- boundary layer stability computed from turbulent fluxes (heat and momentum)

- vertical mixing profile set to variable, with height in the planetary boundary layer (PBL)

- boundary layer depth set from the meteorological model (input meteorology data)

- puff mode dispersion computation, with a "tophat" concentration distribution on a horizontal and vertical scale.

The spatial distribution of $\mathrm{FF} \mathrm{CO}_{2}$ emission sources and their intensities are taken from the ODIAC database. The original ODIAC data were converted into a set of larger pixels $\left(\sim 3.6 \mathrm{~km}^{2}\right)$. Pixels with the area fluxes lower than $8 \mathrm{kt} \mathrm{km}^{-2}$ have been filtered out in order to keep only the urban sources which could be attributed to the St Petersburg agglomeration. The resulting array which was used as the input for HYSPLIT consisted of 376 pixels and is shown in Fig. 3 (bottom). The integral $\mathrm{CO}_{2}$ emission that corresponds to this array equals to $26316 \mathrm{kt} \mathrm{yr}^{-1}$; this is the value being used hereafter as a HYSPLIT first guess.

\subsection{Test simulations of ground-level $\mathrm{CO}_{2}$ concentrations}

Routine measurements of $\mathrm{CO}_{2}$ surface concentrations have been carried out at the atmospheric monitoring station of St Petersburg University in Peterhof $\left(59.88^{\circ} \mathrm{N}, 29.82^{\circ} \mathrm{E}\right)$ since 2013. These observations are the in situ measurements using a gas analyser (Los Gatos Research Inc.; GGA, 24rEP). The instrument is installed on the outskirts of a small town of Peterhof in the suburbs of St Petersburg (see location in Fig. 1). This place is far enough away from busy streets and other local sources of pollution, with an ambient air intake being $3 \mathrm{~m}$ above the surface. To test the HYSPLIT model set-up for the St Petersburg region, we simulated the surface concentration of $\mathrm{CO}_{2}$ near Peterhof, during the 2019 EMME measurement campaign, from 20 March to 30 April 2019. The results of the model calculations were compared to the data of in situ measurements (due to the instrument failure in 2020, the comparison is limited to the period of EMME campaign in 2019 only). Observational data and simulation results were averaged over $3 \mathrm{~h}$ intervals. The resulting comparison is shown in Fig. 4. The model reproduces the temporal variations in $\mathrm{CO}_{2}$, including the main periods of significant growth of concentration; the correlation coefficient between the calculation and measurements is equal to 0.72 . The background value of the surface concentration is taken as $415 \mathrm{ppmv}$ (parts per million by volume) based on the local measurements ( $415 \pm 2 \mathrm{ppmv}$ is the 

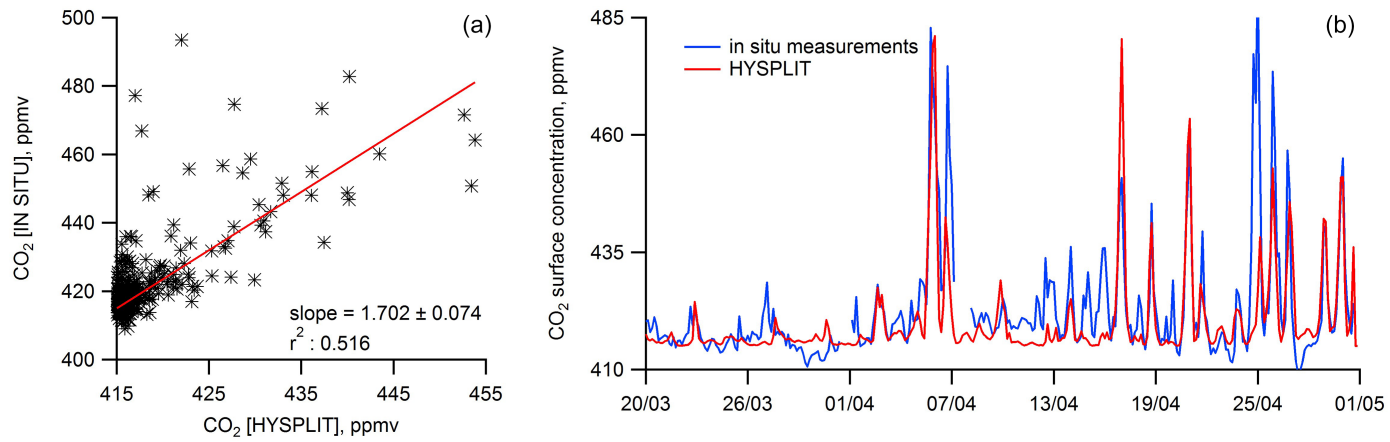

Figure 4. Comparison of the HYSPLIT simulations and the in situ measurements of surface $\mathrm{CO}_{2}$ concentration in Peterhof $\left(59.88^{\circ} \mathrm{N}\right.$, $29.82^{\circ} \mathrm{E}$ ) in March-April 2019. (a) The values of surface $\mathrm{CO}_{2}$ compared with the results of HYSPLIT simulations without the scaling of the ODIAC emissions data. (b) HYSPLIT data obtained using scaled ODIAC $\mathrm{CO}_{2}$ emissions compared with observed surface $\mathrm{CO}_{2}$. Measurement and simulation data are averaged over $3 \mathrm{~h}$ intervals.

mean value of diurnal minima during the campaign from 20 March to 30 April 2019). It is important to emphasize that quantitative agreement is achieved by the linear scaling of the a priori integral urban $\mathrm{CO}_{2}$ emission. The scaling coefficient for emissions corresponds to the value of the integral urban $\mathrm{CO}_{2}$ emission from the territory of St Petersburg of $44800 \pm 1900 \mathrm{kt} \mathrm{yr}^{-1}$ (the given uncertainty is due to the uncertainty of the fitted scaling factor). This value is noticeably higher than official estimates mentioned above and in ODIAC data for 2018 (32529 kt). The average discrepancy between the measurement and simulation data shown in Fig. 4 is $2 \pm 9$ ppmv (model calculations are systematically lower).

\section{Evaluation of integrated $\mathrm{CO}_{2}$ emissions from field FTIR measurements}

\subsection{The results of the EMME-2019 campaign}

We simulated the $\mathrm{CO}_{2}$ total column (TC) spatial distributions over the territory of the St Petersburg agglomeration for the time periods of FTIR mobile measurements conducted in the framework of the EMME-2019 experiment in MarchApril 2019. Obviously, the anthropogenic contribution to the $\mathrm{CO}_{2} \mathrm{TC}$ is concentrated mostly in the lower boundary layer, with a top height of $\sim 200$ to $\sim 1600 \mathrm{~m}$. Therefore, the HYSPLIT model was configured to simulate $\mathrm{CO}_{2}$ concentrations at 10 altitude levels $(0-1500 \mathrm{~m})$, which were then integrated to obtain the $\mathrm{CO}_{2}$ column in the boundary layer. The maps of the $\mathrm{CO}_{2}$ plume obtained in this way show that, for all the analysed experiments, the choice of the location of the upwind and downwind measurement points was correct (see Appendix A; Fig. A1). The differences between the results of FTIR measurements of the $\mathrm{CO}_{2} \mathrm{TC}$ inside and outside the pollution plume $\left(\triangle \mathrm{CO}_{2}\right)$ were compared with the differences in the $\mathrm{CO}_{2}$ column in the boundary layer simulated by HYSPLIT at the corresponding locations. HYSPLIT calculations were performed with a temporal resolution of $15 \mathrm{~min}$. The data series of measured and calculated $\mathrm{CO}_{2}$ contents for the experiments involved in the analysis are shown in separate plots in the Appendix B (Fig. B1). It is clearly seen from the plots that the downwind-upwind enhancements in $\mathrm{CO}_{2}$ observed by the measurements are significantly higher than predicted by HYSPLIT, which indicates an underestimation of inventory $\mathrm{CO}_{2}$ emissions. An example of a simulated $\mathrm{CO}_{2}$ plume and a time series of $\mathrm{CO}_{2}$ total column measurements and HYSPLIT calculations for a typical day of experiments in 2019 (4 April) is given in Fig. 5. For the sake of comparison, the simulation results and measurement data were averaged over time periods of field observations (the duration of each experiment is given in Table 1).

In order to obtain a quantitative agreement between simulated and observed $\Delta \mathrm{CO}_{2}$, the inventory data (the ODIAC emissions), which are used as input information for the HYSPLIT dispersion model, should be scaled (Flesch et al., 2004). The scaling factor (SF) is derived as follows. The data from all days of measurements are compared to the corresponding model simulations (see Fig. 6, left panel, as an example of a scatterplot). The scaling factor is determined as a slope value of the following regression line (e.g. the slope is $2.88 \pm 0.21$, as shown in Fig. 6):

$\Delta \mathrm{CO}_{2}[\mathrm{FTIR}]_{i}=\mathrm{SF} \times \Delta \mathrm{CO}_{2}\left[\mathrm{HYSPLIT}_{\mathrm{ODIAC}_{i}}\right.$,

where $\Delta \mathrm{CO}_{2}[\mathrm{FTIR}]_{i}$ is the difference between the downwind and upwind FTIR measurements averaged over the duration of experiment $i$ (see Tables 1 and 2 and Appendices $\mathrm{A}$ and $\mathrm{B}$ for the details of every field experiment) and $\Delta \mathrm{CO}_{2}\left[\text { HYSPLIT }_{\text {ODIAC }}\right]_{i}$ is the averaged difference between the downwind and upwind $\mathrm{CO}_{2}$ column calculated using the HYSPLIT dispersion model for the location and time of FTIR observations and initialized with ODIAC $\mathrm{CO}_{2}$ emissions.

The error assessment for the scaling factor should be discussed in some detail. The $1 \sigma$ precision for the $\mathrm{XCO}_{2}$ individual measurement is of the order of $0.01 \%-0.02 \%$ 

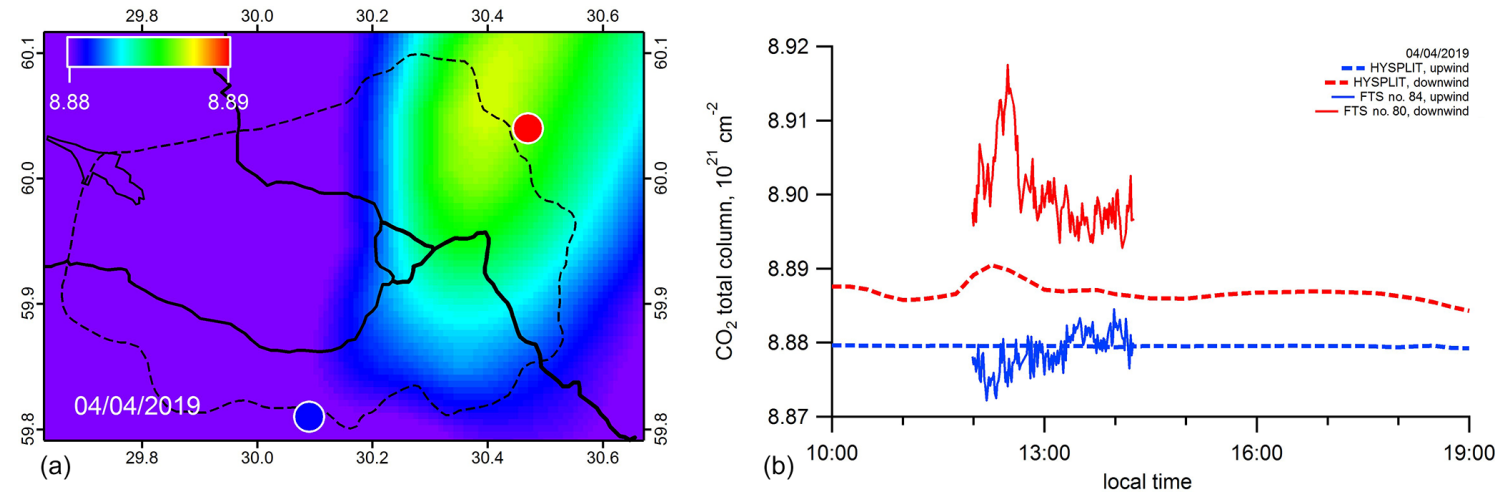

Figure 5. (a) Urban pollution $\mathrm{CO}_{2}$ plume over St Petersburg calculated by the HYSPLIT model for 4 April 2019 (10:00 UTC). The colour bar designates the $\mathrm{CO}_{2}$ total column in units $10^{21} \mathrm{~cm}^{-2}$. The blue and red circles indicate the locations of upwind and downwind FTS observations, accordingly. (b) Time series of measured (FTS) and simulated (HYSPLIT, without scaling of the ODIAC emissions data) $\mathrm{CO}_{2}$ total column at the upwind (blue lines) and downwind (red lines) locations for the same day.
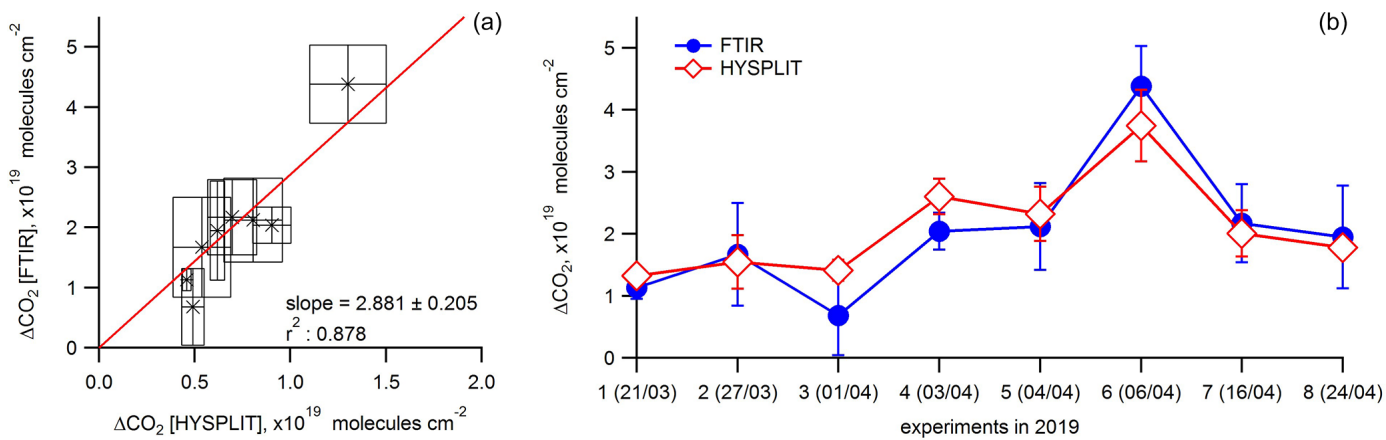

Figure 6. (a) The values of $\Delta \mathrm{CO}_{2}$ (see text) acquired during the field FTIR observations in 2019 compared with the results of the HYSPLIT simulations without the scaling of the ODIAC data. Measurement and simulation data are averaged over time intervals of FTIR measurements. (b) HYSPLIT data obtained using scaled ODIAC $\mathrm{CO}_{2}$ emissions compared with observed $\Delta \mathrm{CO}_{2}$. Dots are connected by lines for illustrative purposes only.

( $<0.08$ ppm, parts per million; e.g. Gisi et al., 2012; Chen et al., 2016; Hedelius et al., 2016; Klappenbach et al., 2015; Vogel et al., 2019). The error of the scaling factor was estimated under the assumption that the measurement errors and the model simulation errors are the same for all days. The error bars indicated in Fig. 6, as boxes, are in fact the variations in $\Delta \mathrm{CO}_{2}$ obtained as a standard deviation of observations and simulations within one observational series (see Appendix B; Fig. B1). Obviously, these quantities comprise both measurement errors and simulation errors (including those associated with wind direction and speed uncertainty) and the temporal variability in the $\mathrm{CO}_{2} \mathrm{TC}$. One can see that these quantities differ from day to day.

Figure $6 \mathrm{~b}$ demonstrates that the model reproduces the evolution of $\Delta \mathrm{CO}_{2}$ recorded in field measurements well; the correlation coefficient between the results of modelling and observations is 0.94 . The derived scaling factor yields the integral anthropogenic $\mathrm{CO}_{2}$ emission value of $75800 \pm$ $5400 \mathrm{kt} \mathrm{yr}^{-1}$; e.g. the value of 75800 results from the multiplication $26316 \times 2.88$ (here 2.88 is the slope on the scatter- plot and 26316 is the model first guess; see Sect. 2.3). The resulting $\mathrm{CO}_{2}$ emission rate is almost twice as high as the above estimate, based on the analysis of ground-level $\mathrm{CO}_{2}$ measurement data (Sect. 2.4, 44800 $\pm 1900 \mathrm{kt} \mathrm{yr}^{-1}$ ). This difference may indicate a significant contribution of elevated $\mathrm{CO}_{2}$ sources (industrial chimneys) that could not be registered by the ground-level in situ measurements, as the elevated exhausts of pollution are more likely to rise up further rather than descend to the ground. In contrast, FTIR measurements of the total column keep being sensitive to these kinds of emissions. In addition, while FTIR measurements implement a cross section of the urban pollution emission zone in a series of multidirectional trajectories (depending on the wind direction), local ground-level in situ measurements at a specific location (Peterhof) cannot capture the contribution of the entire mass of urban emissions. Thus, estimates of integral $\mathrm{CO}_{2}$ emissions based on the interpretation of groundlevel measurements in Peterhof can be considered as being a lower limit of an estimate. 
An earlier analysis of the results of the EMME-2019 measurement campaign focused in particular on inferring the area fluxes of urban $\mathrm{CO}_{2}$ emissions from St Petersburg. In order to achieve this goal, the simplified mass balance approach was applied to the observed $\mathrm{CO}_{2}$ enhancements $\left(\Delta \mathrm{CO}_{2}\right)$, which were attributed to the accumulation of pollution during the air mass movement on its way from the upwind side to the downwind side of the megacity (see Makarova et al., 2021, for full details). Basically, the mass balance approach was adopted in the form of a one-box model, and the area flux $F$ was calculated using the following equation:

$F=\frac{\Delta \mathrm{CO}_{2} \cdot V}{L}$,

where $F$ is the $\mathrm{CO}_{2}$ area flux, $\Delta \mathrm{CO}_{2}$ is the difference between the downwind and upwind FTIR measurements, $V$ is the mean wind speed and $L$ is the mean path length of an air parcel which goes through the urban area (Chen et al., 2016). The obtained mean value of the $\mathrm{CO}_{2}$ area flux was equal to $89 \pm 28 \mathrm{kt} \mathrm{yr}^{-1} \mathrm{~km}^{-2}$ and was attributed to the emission from the city centre. As shown above, in the current study, the application of the HYSPLIT model allowed us to estimate the integral anthropogenic $\mathrm{CO}_{2}$ emission of the entire megacity. In order to check the consistency with previous results, in the present study, we made calculations of area fluxes on the air trajectories of field measurements using the ODIAC emission database scaled to the integral $\mathrm{CO}_{2}$ emission derived from the results of EMME-2019 combined with the HYSPLIT simulations $\left(75800 \pm 5400 \mathrm{kt} \mathrm{yr}^{-1}\right)$. Schematically, the air trajectories corresponding to the 2019 FTIR measurement locations are shown in Fig. 7. These trajectories were simulated as backward trajectories by the HYSPLIT model in the boundary layer of the atmosphere. The resulting values of anthropogenic $\mathrm{CO}_{2}$ area fluxes, calculated by integrating the ODIAC data along these trajectories, are shown in Fig. 8 in comparison with the experimental estimates by Makarova et al. (2021). As in the study by Makarova et al. (2021), the width of the air paths was assumed to be $10 \mathrm{~km}$. On average, according to ODIAC data, the area flux for the 2019 measurement trajectories was $106 \pm 9 \mathrm{kt} \mathrm{yr}^{-1} \mathrm{~km}^{-2}$, which is somewhat higher than the experimental estimates $(89 \pm$ $28 \mathrm{kt} \mathrm{yr}^{-1} \mathrm{~km}^{-2}$ ) but agrees within the error limits. Significantly higher variability in the experimental data may be related to the variability of the wind field, which is not taken into account in the simplified mass balance approach.

\subsection{The results of EMME-2020 and comparison with EMME-2019}

The data of mobile FTIR measurements performed in March-early May 2020 were processed and analysed in the same way as done for the data acquired during the measurement campaign in 2019. An example of a simulated $\mathrm{CO}_{2}$ plume and a time series of $\mathrm{CO}_{2}$ total column measurements and HYSPLIT calculations for a typical day of experiments
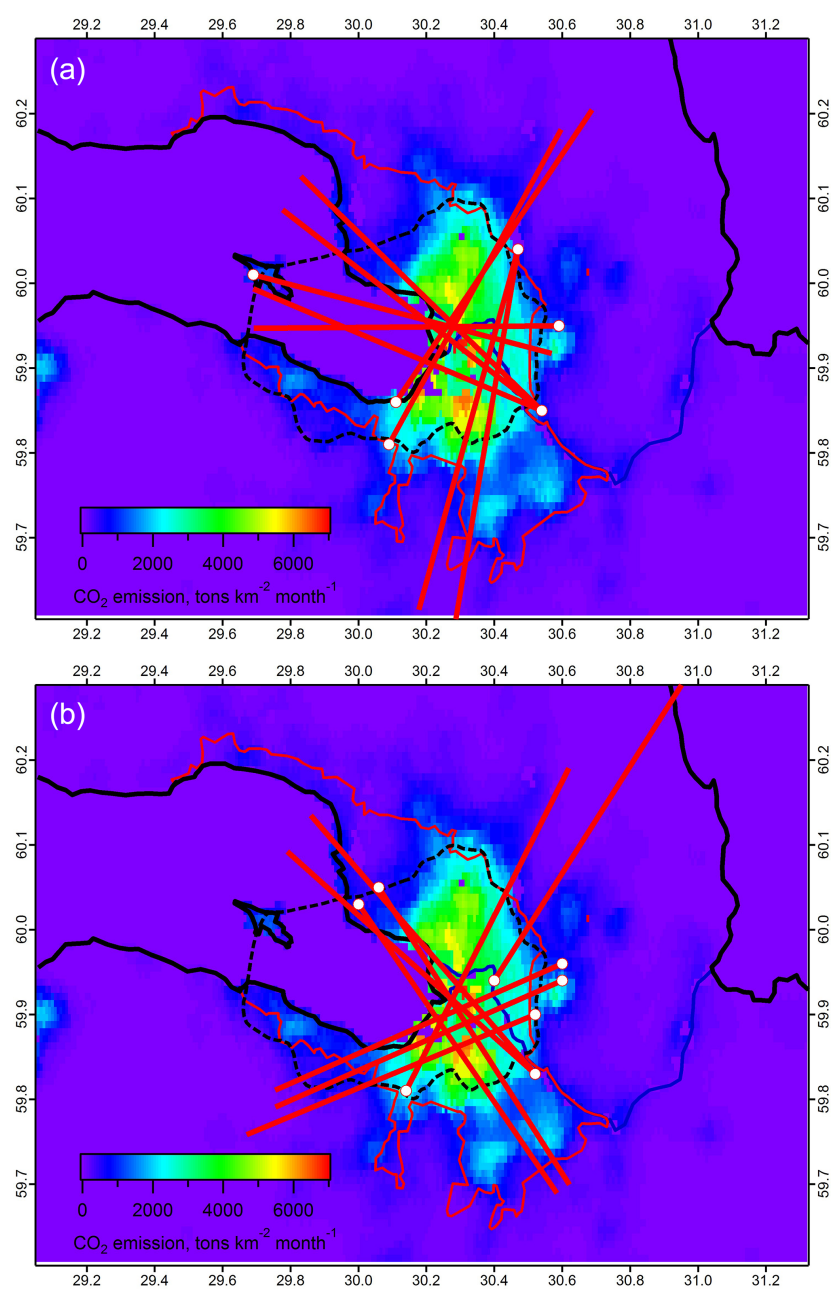

Figure 7. Map of air mass trajectories corresponding to field measurements of EMME experiments in March-April 2019 (a) and March-April 2020 (b). For simplicity, the trajectories are designated by straight lines, $50 \mathrm{~km}$ long, ending at the locations of the downwind FTIR measurements.

in 2020 (8 April) is given in Fig. 9. The comparison of the observed and simulated mean values of $\Delta \mathrm{CO}_{2}$ is shown in Fig. 10. Similar to the results of 2019, the HYSPLIT simulations reproduce the observed evolution of $\Delta \mathrm{CO}_{2}$ well. The correlation coefficient between the simulations and observations is 0.78 . The estimation of the $\mathrm{CO}_{2}$ emission was done using the above-described approach based on the pollution plume modelling by HYSPLIT and scaling the ODIAC data which were taken as an a priori guess. For the EMME-2020 campaign, the derived integral anthropogenic $\mathrm{CO}_{2}$ emission is $68400 \pm 7100 \mathrm{kt} \mathrm{yr}^{-1}$, which is about $10 \%$ lower than the estimate obtained for $2019\left(75800 \pm 5400 \mathrm{kt} \mathrm{yr}^{-1}\right)$.

It should be noted that one can expect lower anthropogenic $\mathrm{CO}_{2}$ emissions in the 2020 measurement data compared to the same period in 2019, since restrictive measures were imposed in St Petersburg on 28 March due to the COVID-2019 pandemic. A number of studies have already reported signif- 


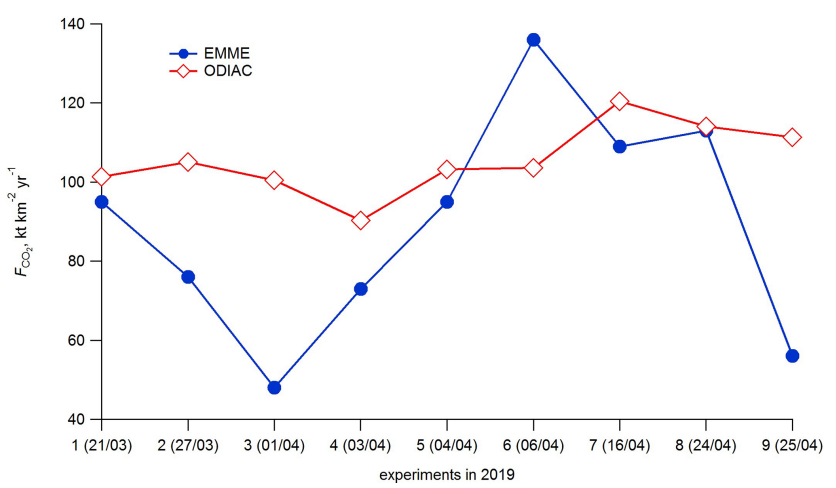

Figure 8. The $\mathrm{CO}_{2}$ area flux $\left(F_{\mathrm{CO}_{2}}\right)$ obtained on the basis of the mass balance approach (EMME-2019) compared to the $\mathrm{CO}_{2}$ area flux derived from scaled ODIAC data. The calculations are made for the trajectories shown in Fig. 7. Dots are connected by lines for illustrative purposes only.

icant reductions of air pollution that followed the lockdown events in different regions of the world (see, e.g., Petetin et al., 2020; Pathakoti et al., 2020; Koukouli et al., 2021). According to Yandex data (https://yandex.ru/covid19/stat, last access: 3 November 2020), the traffic intensity in the city of St Petersburg decreased to $12 \%-26 \%$ of the usual value on weekdays in the first week of quarantine (from 30 March to 3 April) and amounted to $28 \%-33 \%$ in the following week (from 6 April to 10 April). Since we have no official data on the $\mathrm{CO}_{2}$ emissions by traffic at our disposal, we used the average estimate for European countries, according to which the contribution of traffic to total emission constitutes $30 \%$ (European Parliament News, 2020). Under this assumption, a reduction in traffic activity down to $30 \%$ of the normal level should result in a reduction in total anthropogenic $\mathrm{CO}_{2}$ emissions by $21 \%((1.0-(0.7+0.3 \times 0.3)) \times 100 \%)$.

The weak response of urban $\mathrm{CO}_{2}$ emissions to restrictive quarantine measures may indicate a relatively small contribution of traffic to the total $\mathrm{CO}_{2}$ emissions from the territory of St Petersburg. This may be due to the higher contribution of emissions associated with residential heating (including the consumption of natural gas in private residences, e.g. stoves and water boilers), which is more important for a northern city such as St Petersburg and is unlike many European cities. Normally, the heating is still working in St Petersburg in March and April, and the corresponding $\mathrm{CO}_{2}$ emissions cannot be reduced due to the quarantine. Our confident expectation for detecting the transport contribution is based on the high sensitivity of FTIR measurements to $X_{\mathrm{CO}_{2}}$ when using EM27/SUN spectrometers and COCCON methodology. If the emission from traffic were higher, it would definitely have been identified during the campaign. The high sensitivity of our measurements to the $\mathrm{CO}_{2}$ pollution from different sources is demonstrated by the following examples. The results of EMME-2019 revealed that the emission of a single TPP located on the northeastern side of the city (see Fig. 11)
Table 3. The $\mathrm{CO}_{2}$ area fluxes $\left(\mathrm{kt} \mathrm{yr}^{-1} \mathrm{~km}^{-2}\right)$ obtained from mobile FTIR measurements in 2019 and 2020 which were performed under similar observational configurations.

\begin{tabular}{lr}
\hline Measurement date & $\begin{array}{r}\mathrm{CO}_{2} \text { area flux } \\
\left(\mathrm{kt} \mathrm{yr}^{-1} \mathrm{~km}^{-2}\right)\end{array}$ \\
\hline 27 March 2019 & $76 \pm 60$ \\
5 April 2020 & $116 \pm 92$ \\
\hline 1 April 2019 & $48 \pm 38$ \\
8 April 2020 & $89 \pm 70$ \\
\hline
\end{tabular}

can add $\sim 5 \times 10^{19} \mathrm{~mol} \mathrm{~cm}^{-2}$ to the $\mathrm{CO}_{2}$ TC (Makarova et al., 2021). During the 2020 measurement campaign, one of the series of FTIR measurements was performed near the waste processing plant (WPP) on the eastern side of the city (see Fig. 11). The contribution of this local $\mathrm{CO}_{2}$ source was $\sim 1 \times 10^{19} \mathrm{~mol} \mathrm{~cm}^{-2}$. We emphasize that these measurements, being significantly affected by local sources, were excluded from statistical analysis. In general, for these reasons (including unfavourable weather conditions and the wrong location of FTIR measurement points), data from only a few experiments were excluded, i.e. no. 8 on 18 April 2019, no. 10 on 25 April 2019, no. 11 on 30 April 2019 (see Table 1) and no. 4 on 27 March 2020 (see Table 2). However, the given examples indicate the crucial role of stationary, non-transport sources of emissions which were not subject to restrictive quarantine measures.

A thorough analysis of all experiments performed during the 2019 and 2020 measurement campaigns has shown that there were days with similar air trajectories and similar downwind measurement locations. These situations occurred twice, namely on 27 March 2019 and 5 April 2020 and on 1 April 2019 and 8 April 2020 (see Fig. 11). Both series of 2020 measurements, on 5 and 8 April, were performed during the COVID-19 quarantine period. We calculated the $\mathrm{CO}_{2}$ area fluxes for these days by applying the mass balance approach which was used by Makarova et al. (2021). The results are presented in Table 3. Unexpectedly, the estimates indicate an increase in area fluxes during the quarantine period in 2020, compared to the same period in 2019. According to the data of the local weather archive (http://rp5.ru/Weather_archive_in_Saint_Petersburg, last access: 3 November 2020), the mean ambient temperature in St Petersburg was +5.0 and $+3.2^{\circ} \mathrm{C}$ for the period from 27 March to 8 April in 2019 and 2020, accordingly. Thus, somewhat colder weather in 2020 may contribute to the increase in $\mathrm{CO}_{2}$ emission due to the more intense residential heating. However, the high uncertainty of the $\mathrm{CO}_{2}$ area flux estimates due to the uncertainties of the wind field and of the effective path length (for details, see Makarova et al., 2021) does not allow us to gain sufficient confidence in the nature of the detected differences. 

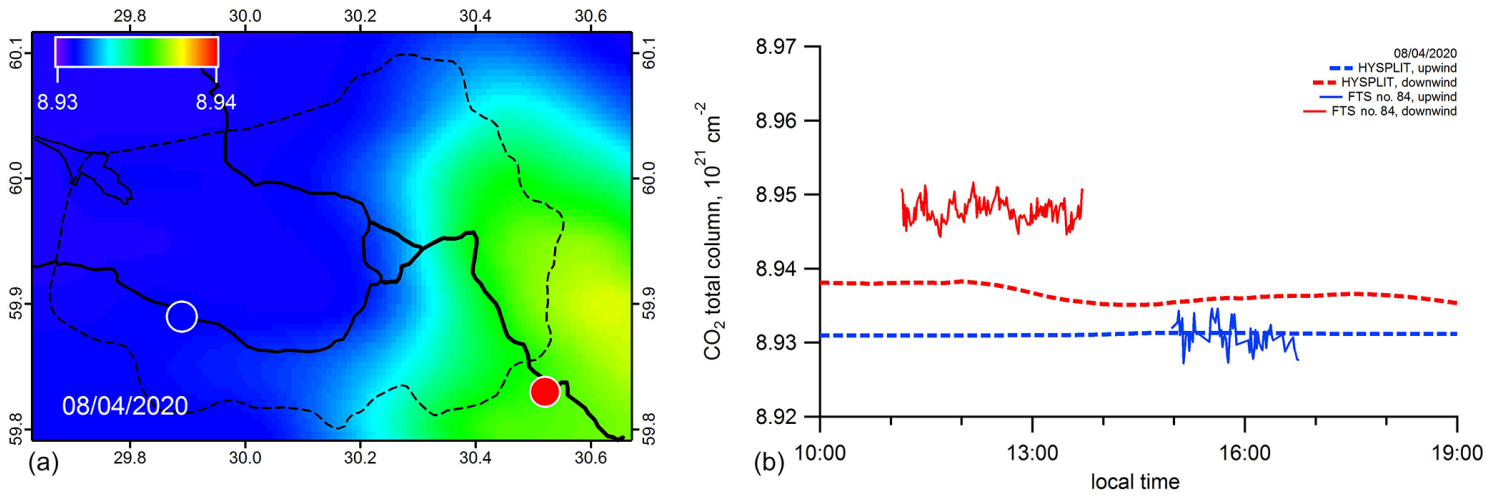

Figure 9. (a) Urban pollution $\mathrm{CO}_{2}$ plume over St Petersburg calculated by the HYSPLIT model for 8 April 2020 (10:00 UTC). The colour bar designates the $\mathrm{CO}_{2}$ total column in units $10^{21} \mathrm{~cm}^{-2}$. The blue and red circles indicate the locations of upwind and downwind FTS observations, accordingly. (b) Time series of measured (FTS) and simulated (HYSPLIT; without scaling of the ODIAC emissions data) $\mathrm{CO}_{2}$ total column at the upwind (blue lines) and downwind (red lines) locations for the same day.
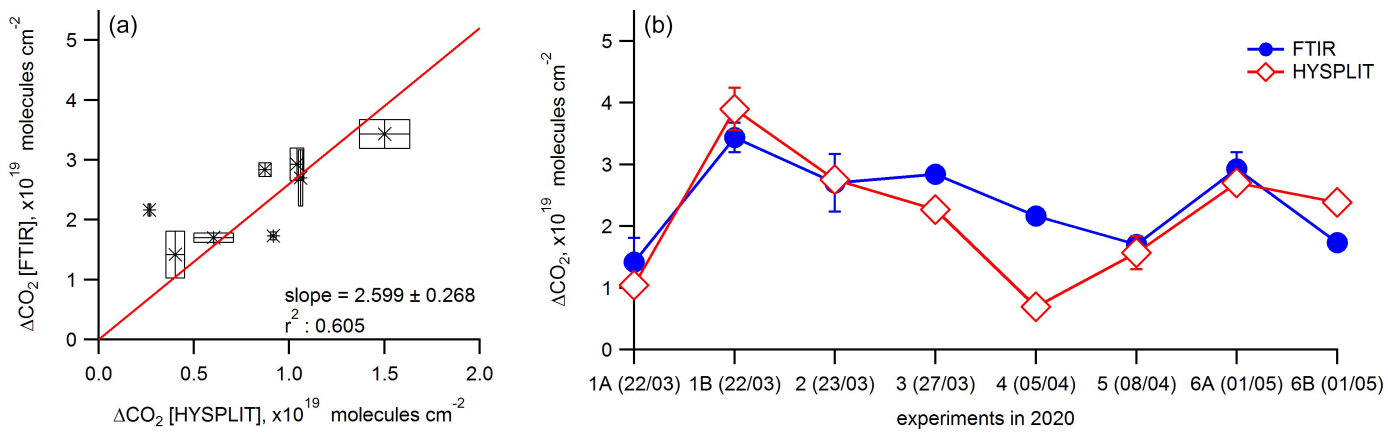

Figure 10. (a) The values of $\Delta \mathrm{CO}_{2}$ (see text) acquired during the field FTIR observations in 2020 compared with the results of HYSPLIT simulations before the process of scaling of the ODIAC data. Measurement and simulation data are averaged over time intervals of FTIR measurements. (b) HYSPLIT data obtained using scaled ODIAC $\mathrm{CO}_{2}$ emissions are compared with observed $\Delta \mathrm{CO}_{2}$. Dots are connected by lines for illustrative purposes only.

In our opinion, the most important finding of our study, based on the analysis of two observational campaigns, is a significantly higher $\mathrm{CO}_{2}$ emission from the megacity of St Petersburg compared to the data of municipal inventory $(\sim$ $75800 \pm 5400 \mathrm{kt} \mathrm{yr}^{-1}$ for 2019 and $\sim 68400 \pm 7100 \mathrm{kt} \mathrm{yr}^{-1}$ for 2020 versus $\sim 30000 \mathrm{kt} \mathrm{yr}^{-1}$ reported by official inventory). Besides, this finding is consistent with the estimate of the $\mathrm{CO}_{2}$ emission area flux by Makarova et al. (2021) which was about double that of the Emission Database for Global Atmospheric Research (EDGAR) inventory for St Petersburg (EDGAR, 2019). The difference can be partly explained by the impact of diurnal and seasonal variations in anthropogenic activity, since our measurements were conducted during the period of maximum $\mathrm{CO}_{2}$ emission (early spring and afternoon) and, therefore, represent the upper limit of the emission estimates. According to the ODIAC data (see Fig. 2) emissions in March and April have to be scaled down by the factor of $\sim 1.07$ to represent the annual average. The global database of hourly scaling factors (Nassar et al., 2013) also gives a factor of $\sim 1.07$ for St Petersburg to scale down the afternoon emission rates to the daily average. So, dividing our estimates twice by 1.07 gives $\sim 59000-$ $-66000 \mathrm{kt} \mathrm{yr}^{-1}$, which is still higher than the official inventory value. Compared to other cities, the integral $\mathrm{CO}_{2}$ emission of St Petersburg is not that high; e.g. the ODIAC inventory reports $\sim 18000 \mathrm{kt} \mathrm{yr}^{-1}$ for San Francisco, $\sim$ $37000 \mathrm{kt} \mathrm{yr}^{-1}$ for Paris, $\sim 51000 \mathrm{kt} \mathrm{yr}^{-1}$ for Mexico, $\sim$ $88000 \mathrm{kt} \mathrm{yr}^{-1}$ for Delhi, $\sim 106000 \mathrm{kt} \mathrm{yr}^{-1}$ for Moscow, $\sim$ $136000 \mathrm{kt} \mathrm{yr}^{-1}$ for Hong Kong, $\sim 172000 \mathrm{kt} \mathrm{yr}^{-1}$ for Tokyo and $\sim 227000 \mathrm{kt} \mathrm{yr}^{-1}$ for Shanghai (the data are taken from the paper by Umezawa et al., 2020; their Fig. 3). Typically, these estimates of urban $\mathrm{CO}_{2}$ emissions are strongly correlated with the city's population, e.g. $\sim 1$ million people in San Francisco and $\sim 23$ million people in Shanghai.

\section{Summary and conclusions}

In 2019 and 2020, in spring, the mobile experiment EMME (Emission Monitoring Mobile Experiment) was carried out on the territory of St Petersburg, which is the second-largest 


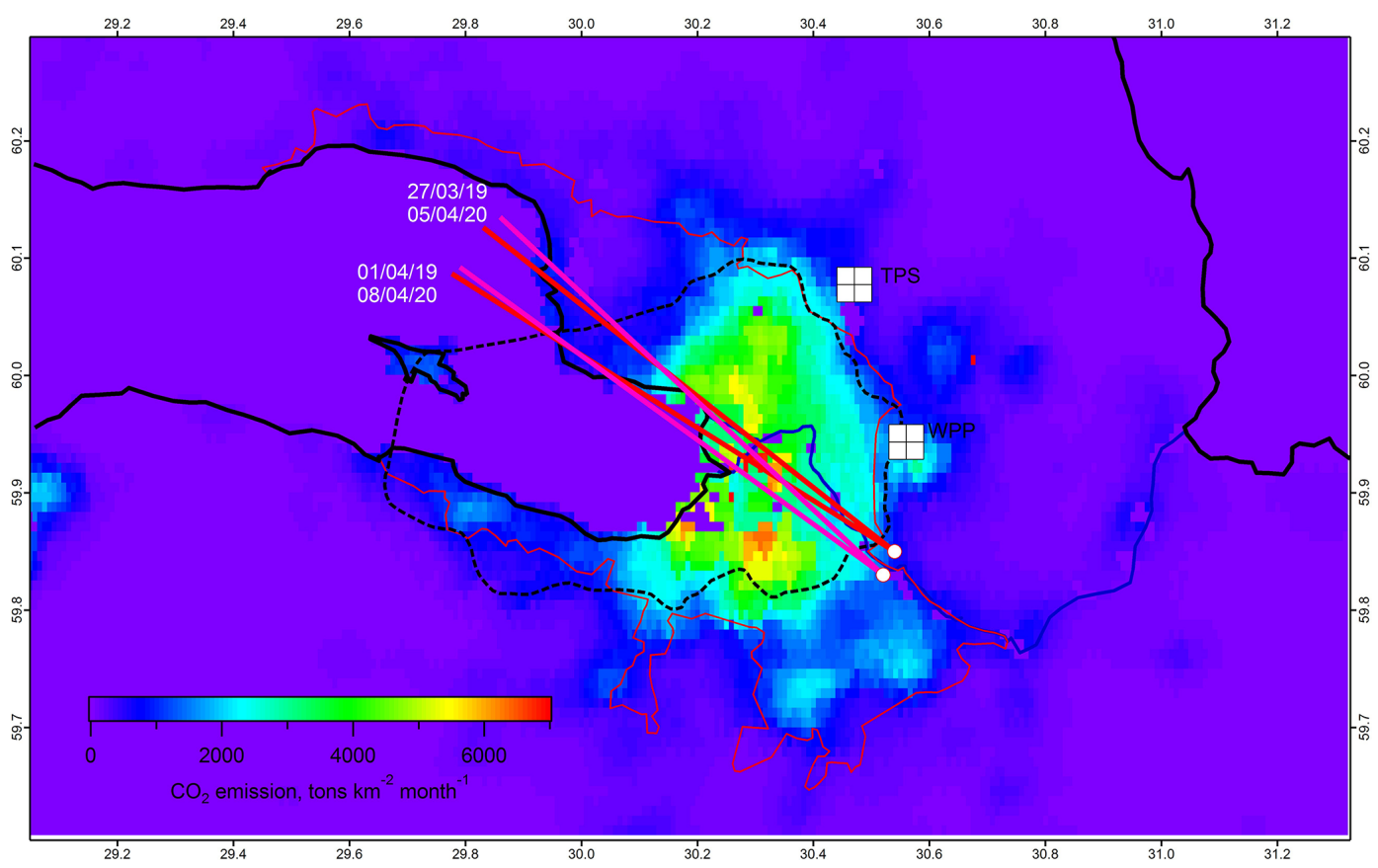

Figure 11. Map of similar air trajectories and similar downwind measurement locations for EMME-2019 and EMME-2020 experiments. For simplicity, the trajectories are marked with straight lines, $50 \mathrm{~km}$ long, ending at the locations of downwind FTIR measurements. The locations of a thermal power station (TPS) on the northeastern side and a solid waste processing plant (WPP) on the eastern side are also indicated.

industrial city in Russia, with a population of more than 5 million. In 2020, several measurement series were obtained during the lockdown period caused by the COVID-19 pandemic. Previously, the $\mathrm{CO}_{2}$ area flux has been obtained from the data of the EMME-2019 experiment using the mass balance approach. The present study is focused on the derivation of the integral $\mathrm{CO}_{2}$ emission from St Petersburg by combining the results of the EMME observational campaigns of 2019 and 2020 and the HYSPLIT model simulations. The ODIAC database is used as the source of the a priori information on the $\mathrm{CO}_{2}$ emissions for the territory of St Petersburg.

A number of studies (Pillai et al., 2016; Broquet et al., 2018; Kuhlmann et al., 2019; Babenhauserheide et al., 2020) have shown that emissions from large $\mathrm{CO}_{2}$ sources (cities and thermal power plants) can be characterized by the difference between the results of measurements of the carbon dioxide concentration in the dry atmospheric column inside and outside of the pollution plume $\left(\triangle \mathrm{XCO}_{2}\right)$. The results of the measurement campaigns in 2019 and 2020 have shown that, for St Petersburg in a set of mobile experiments, the values of $\triangle \mathrm{XCO}_{2}$ averaged over the duration of FTIR observations were in the range of 0.05-4.46 ppmv. For comparison, similar studies revealed the following values of $\triangle \mathrm{XCO}_{2}: 0.16$ 1.03 ppmv for Berlin, Germany (Kuhlmann et al., 2019), 0.80-1.35 ppmv for Paris, France (Pillai et al., 2016; Broquet et al., 2018), and 0-2 ppmv for Tokyo, Japan (Babenhauserheide et al., 2020). So, for St Petersburg, the highest values of $\triangle \mathrm{XCO}_{2}$ were detected (4.46 ppmv) if compared to similar measurements in Berlin, Paris and Tokyo. It should be noted that the value of $\triangle \mathrm{XCO}_{2}$ depends not only on the integral emission of the source but also on its spatial allocation (compact or distributed), the geometry of the field experiment (location of observations relative to the pollution plume) and on the meteorological situation during the measurements. This is why dispersion modelling, taking into account inventories of emission sources, is the most appropriate tool for interpreting the results of such observations.

The HYSPLIT model, coupled with the scaled input from the ODIAC database, reproduces the results of FTIR observations of the $\mathrm{CO}_{2} \mathrm{TC}$ during both campaigns well; the correlation coefficient between the results of modelling and observations is 0.94 for 2019 and 0.78 for 2020 . The lower value of the correlation coefficient for 2020 can be partly explained by the change in the spatial distribution of the $\mathrm{CO}_{2}$ emission sources during the COVID-19 pandemic lockdown, which could differ from the ODIAC distribution of the FF $\mathrm{CO}_{2}$ sources. However, the data are not sufficient to confirm this suggestion. The most important finding of the study, based on the analysis of two observational campaigns, is a significantly higher $\mathrm{CO}_{2}$ emission from the megacity of St Petersburg compared to the data of municipal inventory, i.e. $\sim 75800 \pm 5400 \mathrm{kt} \mathrm{yr}^{-1}$ for 2019 and $\sim 68400 \pm$ $7100 \mathrm{kt} \mathrm{yr}^{-1}$ for 2020 versus $\sim 30000 \mathrm{kt} \mathrm{yr}^{-1}$ reported by official inventory. The comparison of $\mathrm{CO}_{2}$ emissions obtained during the COVID-19 lockdown period in 2020 to the results 
obtained during the same period of 2019 demonstrated a decrease of $10 \%$ or $7400 \mathrm{kt} \mathrm{yr}^{-1}$ in emission.

There was an attempt to simulate the in situ measurements of the $\mathrm{CO}_{2}$ concentration performed at the observational site located in the suburb of the St Petersburg megacity during the two-month period (March-April 2019). In this case, the correlation coefficient between model simulations and observations was 0.72 . In contrast to the estimates of the $\mathrm{CO}_{2}$ emissions from FTIR measurements presented above, the simulation of in situ measurements gives a much lower value (by a factor of 1.5-1.7) of the $\mathrm{CO}_{2}$ integrated emission, i.e. $44800 \pm 1900 \mathrm{kt} \mathrm{yr}^{-1}$. Similar differences were previously found between estimates of the $\mathrm{CO}_{2}$ area fluxes for the central part of St Petersburg, obtained from both the analysis of FTIR measurements and from in situ measurements of $\mathrm{CO}_{2}$ concentration (Makarova et al., 2021). This fact may indicate a significant contribution of elevated $\mathrm{CO}_{2}$ sources (industrial chimneys) that could not be registered by the groundlevel in situ measurements (in contrast to FTIR measurements of the total column). The approach of monitoring the outflows of large cities using arrays of compact FTIR spectrometers seems a promising and cost-effective route for assessing and monitoring the $\mathrm{CO}_{2}$ emissions of these important sources. Recurring campaigns performed over extended periods or even the erection of permanent observatories, as demonstrated by Chen et al. (2016) and Dietrich et al. (2021), should be recognized as being crucial components of strategies aiming at improved observational capacity for greenhouse gases on regional and urban domains. 
Appendix A: Location of ground-based measurement points with respect to the urban pollution plume

The location of FTS field measurements is shown on the maps of vertically integrated $\mathrm{CO}_{2}$ (total column - TC) produced by HYSPLIT for selected campaign days in 2019 and 2020 (10:00 UTC; see Figs. A1 and A2). The locations of the FTS instruments on the upwind and downwind sides are indicated by blue and red circles, respectively. Note that, in 2020, there were days when the downwind measurements were performed twice, on 23 March and 1 May, at different locations (see Fig. A2). 

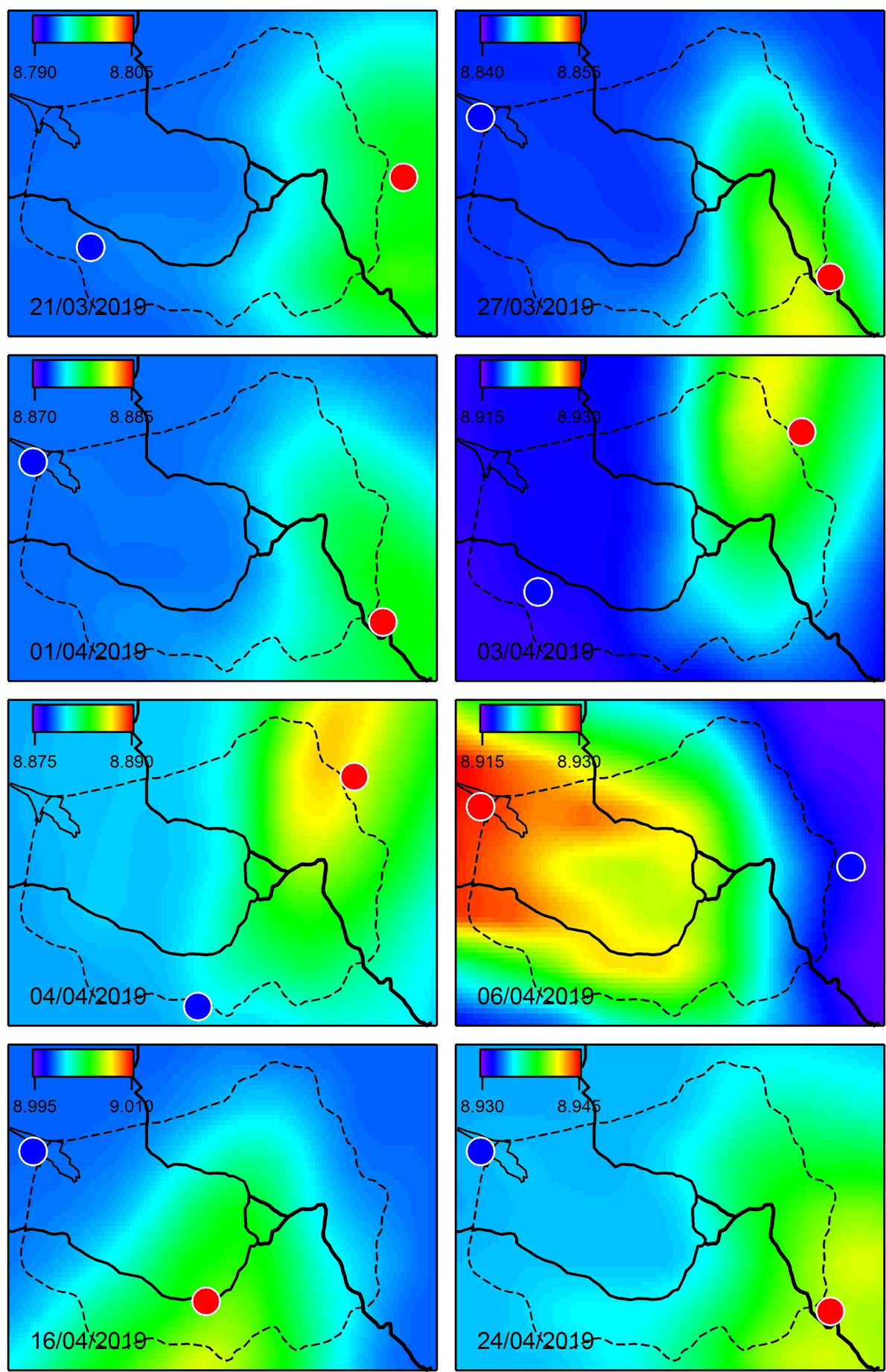

Figure A1. Urban pollution $\mathrm{CO}_{2}$ plume over St Petersburg calculated with HYSPLIT model for the days of field campaign in 2019 (10:00 UTC). The colour bar units for $\mathrm{TC}_{\mathrm{CO}_{2}}$ are $10^{21} \mathrm{~cm}^{-2}$. The blue and red circles indicate the locations of upwind and downwind FTS observations, accordingly. 

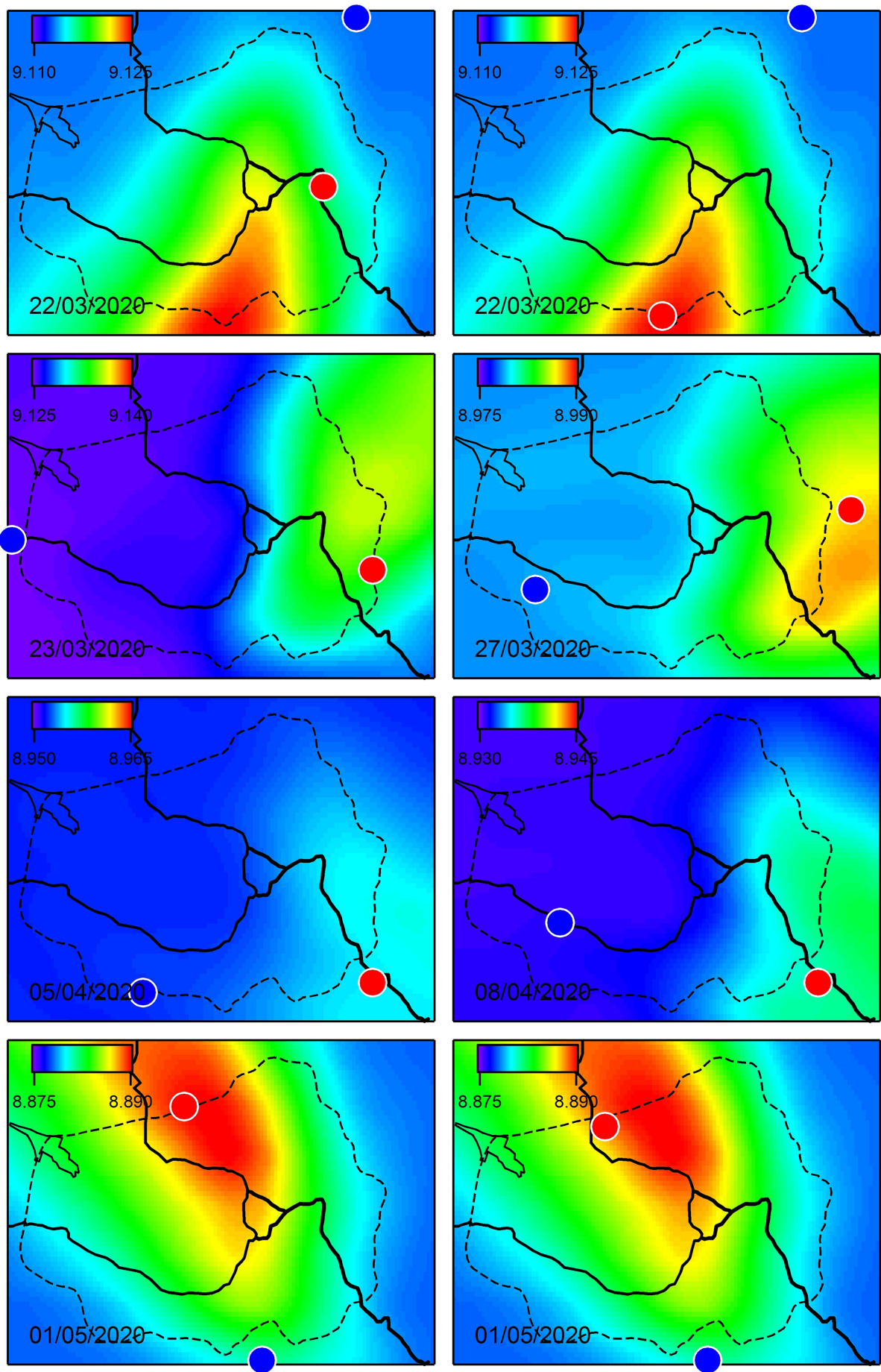

Figure A2. Urban pollution $\mathrm{CO}_{2}$ plume over St Petersburg calculated with HYSPLIT model for the days of field campaign in 2020 (10:00 UTC). The colour bar units for $\mathrm{TC}_{\mathrm{CO}_{2}}$ are $10^{21} \mathrm{~cm}^{-2}$. The blue and red circles indicate the locations of upwind and downwind FTS observations, accordingly. 
Appendix B: The data series of measured and calculated $\mathrm{CO}_{2}$ content

The upwind and downwind $\mathrm{CO}_{2}$ total column values acquired from FTIR measurements and HYSPLIT calculations are shown for selected campaign days in 2019 and 2020 in Figs. B1 and B2. The HYSPLIT data are, in fact, the values of an integrated vertical column in the range of $0-1500 \mathrm{~m}$ (10 altitude layers) calculated with the $15 \mathrm{~min}$ time step. The background level of the $\mathrm{CO}_{2}$ column is set equal to an average of the FTIR upwind measurements during a day. Note that, in 2020, there were days when the downwind measurements were performed twice, on 22 March and 1 May, at different locations (see Fig. B2). 

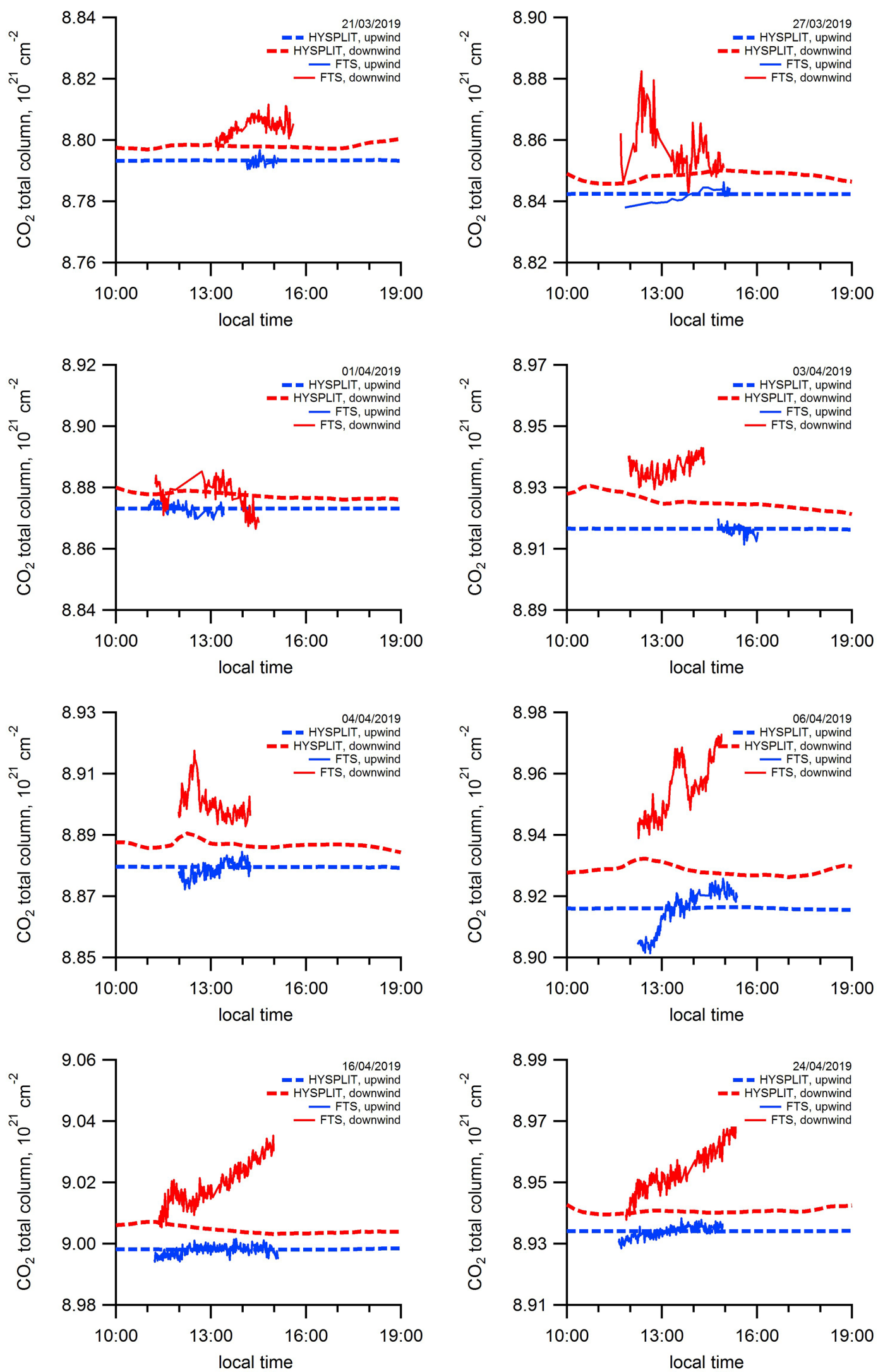

Figure B1. Time series of measured (FTS) and simulated (HYSPLIT; without scaling of the ODIAC emissions data) $\mathrm{CO}_{2}$ total column at the upwind (blue lines) and downwind (red lines) locations for selected campaign days in 2019. 

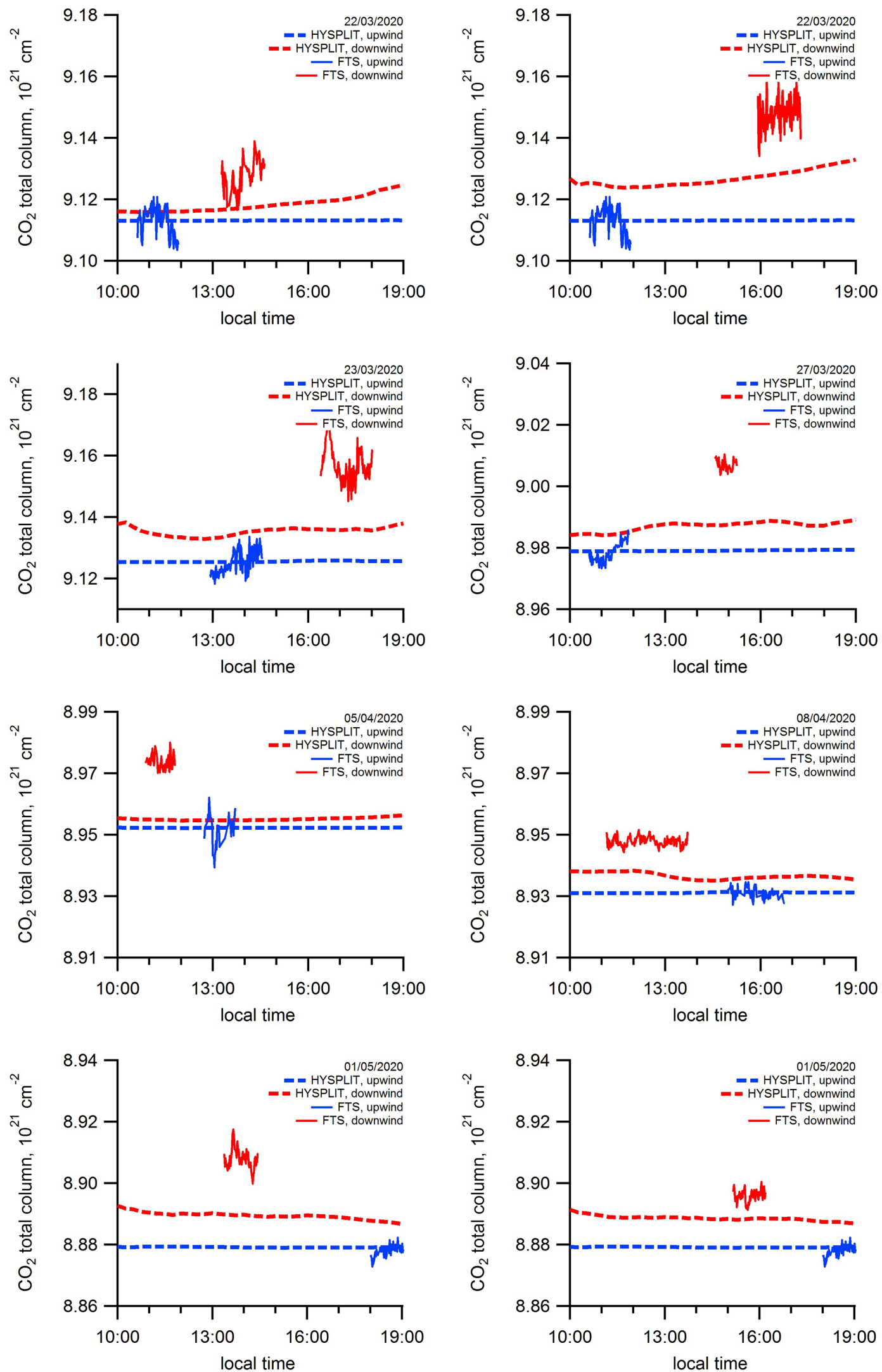

Figure B2. Time series of measured (FTS) and simulated (HYSPLIT; without scaling of the ODIAC emissions data) $\mathrm{CO}_{2}$ total column at the upwind (blue lines) and downwind (red lines) locations for selected campaign days in 2020. 
Data availability. The data sets containing the EM27/SUN measurements during EMME-2019 and EMME-2020 can be provided upon request; please contact Maria V. Makarova (m.makarova@spbu.ru) and Frank Hase (frank.hase@kit.edu).

Author contributions. DVI and MVM conceived the study. MVM, DVI, FH, CA, VSK and SCF contributed greatly to the experimental part of the study. SCF, CA and MVM were in charge of processing the FTIR spectrometer data. DVI was in charge of numerical modelling by HYSPLIT. Together, DVI, MVM, FH, TB, SCF, CA, VSK and TW analysed and interpreted the results. DVI, MVM and VSK prepared the original draft. Together, DVI, MVM, FH, TB, SCF, CA, VSK and TW reviewed and edited the paper.

Competing interests. The authors declare that they have no conflict of interest.

Disclaimer. Publisher's note: Copernicus Publications remains neutral with regard to jurisdictional claims in published maps and institutional affiliations.

Acknowledgements. In total, two portable FTIR spectrometers (EM27/SUN) were provided to St Petersburg State University, Russia, by the Karlsruhe Institute of Technology, Germany, in compliance with the conditions of temporary importation in the frame of the VERIFY project. The procedure of the temporary importation of the instruments to the Russian Federation was conducted by the University of Bremen, Germany. The authors acknowledge support from the Helmholtz Association in the framework of MOSES (Modular Observation Solutions for Earth Systems). The development of the COCCON data processing tools was supported by ESA in the framework of the projects COCCON-PROCEEDS and COCCON-PROCEEDS II. Ancillary experimental data were acquired using the scientific equipment of the Geomodel research centre of the St Petersburg State University. The authors acknowledge the participation of Anatoly V. Poberovskii in the field measurement campaigns. The authors gratefully acknowledge the NOAA Air Resources Laboratory (ARL) for the provision of the HYSPLIT transport and dispersion model used in this publication.

Financial support. This research has been supported by the Russian Foundation for Basic Research (grant no. 18-05-00011) and the European Commission, H2020 Research Infrastructures (VERIFY; grant no. 776810).

The article processing charges for this open-access publication were covered by the Karlsruhe Institute of Technology (KIT).

Review statement. This paper was edited by Stefano Galmarini and reviewed by two anonymous referees.

\section{References}

Ahmadov, R., Gerbig, C., Kretschmer, R., Körner, S., Rödenbeck, C., Bousquet, P., and Ramonet, M.: Comparing high resolution WRF-VPRM simulations and two global $\mathrm{CO}_{2}$ transport models with coastal tower measurements of $\mathrm{CO}_{2}$, Biogeosciences, 6, 807-817, https://doi.org/10.5194/bg-6-807-2009, 2009.

Airparif: Air quality monitoring network, available at: https://www. airparif.asso.fr/, last access: 20 May 2020.

Babenhauserheide, A., Hase, F., and Morino, I.: Net $\mathrm{CO}_{2}$ fossil fuel emissions of Tokyo estimated directly from measurements of the Tsukuba TCCON site and radiosondes, Atmos. Meas. Tech., 13, 2697-2710, https://doi.org/10.5194/amt-13-2697-2020, 2020.

Bergeron, O. and Strachan, I. B.: $\mathrm{CO}_{2}$ sources and sinks in urban and suburban areas of a northern mid-latitude city, Atmos. Environ., 45, 1564-1573, https://doi.org/10.1016/j.atmosenv.2010.12.043, 2011.

Bovensmann, H., Buchwitz, M., Burrows, J. P., Reuter, M., Krings, T., Gerilowski, K., Schneising, O., Heymann, J., Tretner, A., and Erzinger, J.: A remote sensing technique for global monitoring of power plant $\mathrm{CO}_{2}$ emissions from space and related applications, Atmos. Meas. Tech., 3, 781-811, https://doi.org/10.5194/amt-3781-2010, 2010.

Bréon, F. M., Broquet, G., Puygrenier, V., Chevallier, F., XuerefRemy, I., Ramonet, M., Dieudonné, E., Lopez, M., Schmidt, M., Perrussel, O., and Ciais, P.: An attempt at estimating Paris area $\mathrm{CO}_{2}$ emissions from atmospheric concentration measurements, Atmos. Chem. Phys., 15, 1707-1724, https://doi.org/10.5194/acp-15-1707-2015, 2015.

Broquet, G., Bréon, F.-M., Renault, E., Buchwitz, M., Reuter, M., Bovensmann, H., Chevallier, F., Wu, L., and Ciais, P.: The potential of satellite spectro-imagery for monitoring $\mathrm{CO}_{2}$ emissions from large cities, Atmos. Meas. Tech., 11, 681-708, https://doi.org/10.5194/amt-11-681-2018, 2018.

Canadell, J. G., Ciais, P., Dhakal, S., Dolman, H., Friedlingstein, P., Gurney, K. R., Held, A., Jackson, R. B., Le Quéré, C., Malone, E. L., Ojima, D. S., Patwardhan, A., Peters, G. P., and Raupach, M. R.: Interactions of the carbon cycle, human activity, and the climate system: a research portfolio, Curr. Opin. Environ. Sustain., 2, 301-311, https://doi.org/10.1016/j.cosust.2010.08.003, 2010.

Chen, J., Viatte, C., Hedelius, J. K., Jones, T., Franklin, J. E., Parker, H., Gottlieb, E. W., Wennberg, P. O., Dubey, M. K., and Wofsy, S. C.: Differential column measurements using compact solartracking spectrometers, Atmos. Chem. Phys., 16, 8479-8498, https://doi.org/10.5194/acp-16-8479-2016, 2016.

Ciais, P., Bousquet, P., Freibauer, A., and Naegler, T.: Horizontal displacement of carbon associated with agriculture and its impacts on atmospheric $\mathrm{CO}_{2}$, Global. Biogeochem. Cy., 21, Gb2014, https://doi.org/10.1029/2006gb002741, 2007.

Ciais, P., Crisp, D., Gon, H. v. d., Engelen, R., Heimann, M., Janssens-Maenhout, G., Rayner, P., and Scholze, M.: Towards a European Operational Observing System to Monitor Fossil $\mathrm{CO}_{2}$ emissions - Final Report from the expert group, European Commission, Copernicus Climate Change Service, Report, Brussels, available at: https://www.copernicus.eu/sites/default/files/ 2019-09/CO2_Blue_report_2015.pdf (last access: 20 July 2021), 2015.

COCCON: COllaborative Carbon Column Observing Network, available at: http://www.imk-asf.kit.edu/english/COCCON.php, last access: 19 March 2021. 
Dietrich, F., Chen, J., Voggenreiter, B., Aigner, P., Nachtigall, N., and Reger, B.: MUCCnet: Munich Urban Carbon Column network, Atmos. Meas. Tech., 14, 1111-1126, https://doi.org/10.5194/amt-14-1111-2021, 2021.

Draxler, R. R. and Hess, G. D.: An overview of the HYSPLIT_4 modelling system for trajectories, dispersion, and deposition, Aust. Meteor. Mag., 47, 295-308, 1998.

Duren, R. M. and Miller, C. E.: Measuring the carbon emissions of megacities, Nat. Clim. Change, 2, 560-562, https://doi.org/10.1038/nclimate1629, 2012.

EDGAR: Emission Database for Global Atmospheric Research, available at: https://edgar.jrc.ec.europa.eu/overview.php? v=CO2ts1990-2011, last access: 21 November 2019.

European Parliament News: $\mathrm{CO}_{2}$ emissions from cars: facts and figures, available at: https://www.europarl.europa.eu/ news/en/headlines/society/20190313STO31218, last access: 20 May 2020.

Flesch, T., Wilson, J., Harper, L., Crenna, B., and Sharpe, R.: Deducing Ground-to-Air Emissions from Observed Trace Gas Concentrations: A Field Trial, J. Appl. Meteorol., 43, 487-502, https://doi.org/10.1175/15200450(2004)043<0487:DGEFOT>2.0.CO;2, 2004.

FLUXNET: FLUXNET, available at: https://fluxnet.fluxdata.org/, last access: 20 May 2020.

Foka, S. Ch., Makarova, M. V., Poberovsky, A. V., and Timofeev, Yu. M.: Temporal variations in $\mathrm{CO}_{2}, \mathrm{CH}_{4}$ and $\mathrm{CO}$ concentrations in Saint-Petersburg suburb (Peterhof), Optika Atmosfery i Okeana, 32, 860-866, 2019 (in Russian).

Frey, M., Hase, F., Blumenstock, T., Groß, J., Kiel, M., Mengistu Tsidu, G., Schäfer, K., Sha, M. K., and Orphal, J.: Calibration and instrumental line shape characterization of a set of portable FTIR spectrometers for detecting greenhouse gas emissions, Atmos. Meas. Tech., 8, 3047-3057, https://doi.org/10.5194/amt-83047-2015, 2015.

Frey, M., Sha, M. K., Hase, F., Kiel, M., Blumenstock, T., Harig, R., Surawicz, G., Deutscher, N. M., Shiomi, K., Franklin, J. E., Bösch, H., Chen, J., Grutter, M., Ohyama, H., Sun, Y., Butz, A., Mengistu Tsidu, G., Ene, D., Wunch, D., Cao, Z., Garcia, O., Ramonet, M., Vogel, F., and Orphal, J.: Building the COllaborative Carbon Column Observing Network (COCCON): long-term stability and ensemble performance of the EM27/SUN Fourier transform spectrometer, Atmos. Meas. Tech., 12, 1513-1530, https://doi.org/10.5194/amt-12-1513-2019, 2019.

Gisi, M., Hase, F., Dohe, S., and Blumenstock, T.: Camtracker: a new camera controlled high precision solar tracker system for FTIR-spectrometers, Atmos. Meas. Tech., 4, 47-54, https://doi.org/10.5194/amt-4-47-2011, 2011.

Gisi, M., Hase, F., Dohe, S., Blumenstock, T., Simon, A., and Keens, A.: $\mathrm{XCO}_{2}$-measurements with a tabletop FTS using solar absorption spectroscopy, Atmos. Meas. Tech., 5, 2969-2980, https://doi.org/10.5194/amt-5-2969-2012, 2012.

Göckede, M., Michalak, A. M., Vickers, D., Turner, D. P., and Law, B. E.: Atmospheric inverse modeling to constrain regional-scale $\mathrm{CO}_{2}$ budgets at high spatial and temporal resolution, J. Geophys.Res.-Atmos., 115, D15113, https://doi.org/10.1029/2009JD012257, 2010.

Gurney, K. R., Law, R. M., Denning, A. S., Rayner, P. J., Baker, D., Bousquet, P., Bruhwiler, L., Chen, Y. H., Ciais, P., Fan, S., Fung, I. Y., Gloor, M., Heimann, M., Higuchi, K., John, J., Maki,
T., Maksyutov, S., Masarie, K., Peylin, P., Prather, M., Pak, B. C., Randerson, J., Sarmiento, J., Taguchi, S., Takahashi, T., and Yuen, C. W.: Towards robust regional estimates of $\mathrm{CO}_{2}$ sources and sinks using atmospheric transport models, Nature, 415, 626630, https://doi.org/10.1038/415626a, 2002.

Hase, F., Frey, M., Blumenstock, T., Groß, J., Kiel, M., Kohlhepp, R., Mengistu Tsidu, G., Schäfer, K., Sha, M. K., and Orphal, J.: Application of portable FTIR spectrometers for detecting greenhouse gas emissions of the major city Berlin, Atmos. Meas. Tech., 8, 3059-3068, https://doi.org/10.5194/amt-8-3059-2015, 2015.

Hase, F., Frey, M., Kiel, M., Blumenstock, T., Harig, R., Keens, A., and Orphal, J.: Addition of a channel for XCO observations to a portable FTIR spectrometer for greenhouse gas measurements, Atmos. Meas. Tech., 9, 2303-2313, https://doi.org/10.5194/amt9-2303-2016, 2016.

Hedelius, J. K., Viatte, C., Wunch, D., Roehl, C. M., Toon, G. C., Chen, J., Jones, T., Wofsy, S. C., Franklin, J. E., Parker, H., Dubey, M. K., and Wennberg, P. O.: Assessment of errors and biases in retrievals of $\mathrm{XCO}_{2}, \mathrm{XCH}_{4}, \mathrm{XCO}$, and $\mathrm{XN}_{2} \mathrm{O}$ from a $0.5 \mathrm{~cm}^{-1}$ resolution solar-viewing spectrometer, Atmos. Meas. Tech., 9, 3527-3546, https://doi.org/10.5194/amt-9-3527-2016, 2016.

Hiller, R. V., Neininger, B., Brunner, D., Gerbig, C., Bretscher, D., Künzle, T., Buchmann, N., and Eugster, W.: Aircraft-based $\mathrm{CH}_{4}$ flux estimates for validation of emissions from an agriculturally dominated area in Switzerland, J. Geophys. Res.-Atmos., 119, 4874-4887, https://doi.org/10.1002/2013JD020918, 2014.

ICOS: Integrated Carbon Observation System, available at: https: //www.icos-ri.eu, last access: 20 May 2020.

IG3IS: Integrated Global Greenhouse Gas Information System, available at: https://ig3is.wmo.int/en, last access: 28 May 2020.

Ionov, D. V. and Poberovskii, A. V.: Observations of urban $\mathrm{NO}_{x}$ plume dispersion using the mobile and satellite DOAS measurements around the megacity of St. Petersburg (Russia), Int. J. Remote Sens., 40, 719-733, https://doi.org/10.1080/01431161.2018.1519274, 2019.

Keppel-Aleks, G., Toon, G. C., Wennberg, P. O., and Deutscher, N. M.: Reducing the impact of source brightness fluctuations on spectra obtained by Fourier-transform spectrometry, Appl. Optics, 46, 4774-4779, https://doi.org/10.1364/AO.46.004774, 2007.

Klappenbach, F., Bertleff, M., Kostinek, J., Hase, F., Blumenstock, T., Agusti-Panareda, A., Razinger, M., and Butz, A.: Accurate mobile remote sensing of $\mathrm{XCO}_{2}$ and $\mathrm{XCH}_{4}$ latitudinal transects from aboard a research vessel, Atmos. Meas. Tech., 8, 50235038, https://doi.org/10.5194/amt-8-5023-2015, 2015.

Koukouli, M.-E., Skoulidou, I., Karavias, A., Parcharidis, I., Balis, D., Manders, A., Segers, A., Eskes, H., and van Geffen, J.: Sudden changes in nitrogen dioxide emissions over Greece due to lockdown after the outbreak of COVID-19, Atmos. Chem. Phys., 21, 1759-1774, https://doi.org/10.5194/acp-211759-2021, 2021.

Kuhlmann, G., Broquet, G., Marshall, J., Clément, V., Löscher, A., Meijer, Y., and Brunner, D.: Detectability of $\mathrm{CO}_{2}$ emission plumes of cities and power plants with the Copernicus Anthropogenic $\mathrm{CO}_{2}$ Monitoring (CO2M) mission, Atmos. Meas. Tech., 12, 6695-6719, https://doi.org/10.5194/amt-126695-2019, 2019. 
Levin, I., Hammer, S., Eichelmann, E., and Vogel, F. R.: Verification of greenhouse gas emission reductions: the prospect of atmospheric monitoring in polluted areas, Philos. T. Roy. Soc. A, 369, 1906-1924, https://doi.org/10.1098/rsta.2010.0249, 2011.

Lopez, M., Schmidt, M., Delmotte, M., Colomb, A., Gros, V., Janssen, C., Lehman, S. J., Mondelain, D., Perrussel, O., Ramonet, M., Xueref-Remy, I., and Bousquet, P.: CO, $\mathrm{NO}_{x}$ and ${ }^{13} \mathrm{CO}_{2}$ as tracers for fossil fuel $\mathrm{CO}_{2}$ : results from a pilot study in Paris during winter 2010, Atmos. Chem. Phys., 13, 7343-7358, https://doi.org/10.5194/acp-13-7343-2013, 2013.

Luther, A., Kleinschek, R., Scheidweiler, L., Defratyka, S., Stanisavljevic, M., Forstmaier, A., Dandocsi, A., Wolff, S., Dubravica, D., Wildmann, N., Kostinek, J., Jöckel, P., Nickl, A.L., Klausner, T., Hase, F., Frey, M., Chen, J., Dietrich, F., Neçcki, J., Swolkień, J., Fix, A., Roiger, A., and Butz, A.: Quantifying CH4 emissions from hard coal mines using mobile sun-viewing Fourier transform spectrometry, Atmos. Meas. Tech., 12, 52175230, https://doi.org/10.5194/amt-12-5217-2019, 2019.

Makarova, M. V., Arabadzhyan, D. K., Foka, S. C., Paramonova, N. N., Poberovskii, A. V., Timofeev, Yu. M., Pankratova, N. V., and Rakitin, V. S.: Estimation of Nocturnal Area Fluxes of Carbon Cycle Gases in Saint Petersburg Suburbs, Russ. Meteorol. Hydrol., 43, 449-455, https://doi.org/10.3103/S106837391807004X, 2018.

Makarova, M. V., Alberti, C., Ionov, D. V., Hase, F., Foka, S. C., Blumenstock, T., Warneke, T., Virolainen, Y. A., Kostsov, V. S., Frey, M., Poberovskii, A. V., Timofeyev, Y. M., Paramonova, N. N., Volkova, K. A., Zaitsev, N. A., Biryukov, E. Y., Osipov, S. I., Makarov, B. K., Polyakov, A. V., Ivakhov, V. M., Imhasin, H. Kh., and Mikhailov, E. F.: Emission Monitoring Mobile Experiment (EMME): an overview and first results of the St. Petersburg megacity campaign 2019, Atmos. Meas. Tech., 14, 1047-1073, https://doi.org/10.5194/amt-14-1047-2021, 2021.

Mays, K. L., Shepson, P. B., Stirm, B. H., Karion, A., Sweeney, C., and Gurney, K. R.: Aircraft-based measurements of the carbon footprint of Indianapolis, Environ. Sci. Technol., 43, 7816-7823, https://doi.org/10.1021/es901326b, 2009.

Nassar, R., Napier-Linton, L., Gurney, K. R., Andres, R. J., Oda, T., Vogel, F. R., and Deng, F.: Improving the temporal and spatial distribution of $\mathrm{CO}_{2}$ emissions from global fossil fuel emission data sets, J. Geophys. Res.-Atmos., 118, 917-933, https://doi.org/10.1029/2012JD018196, 2013.

NCEP GDAS half-degree archive: National Centers for Environmental Prediction Global Forecast System, available at: http: //www.ndaccdemo.org/, last access: 10 June 2020.

NOAA ESRL:, Earth System Research Laboratories, available at: https://www.esrl.noaa.gov/, last access: 20 May 2020.

Oda, T. and Maksyutov, S.: A very high-resolution $(1 \mathrm{~km} \times 1 \mathrm{~km})$ global fossil fuel $\mathrm{CO}_{2}$ emission inventory derived using a point source database and satellite observations of nighttime lights, Atmos. Chem. Phys., 11, 543-556, https://doi.org/10.5194/acp-11543-2011, 2011.

Oda, T. and Maksyutov, S.: ODIAC Fossil Fuel $\mathrm{CO}_{2}$ Emissions Dataset (Version name: ODIAC2019), Center for Global Environmental Research, National Institute for Environmental Studies, https://doi.org/10.17595/20170411.001, 2020.

Oda, T., Maksyutov, S., and Andres, R. J.: The Open-source Data Inventory for Anthropogenic $\mathrm{CO}_{2}$, version 2016 (ODIAC2016): a global monthly fossil fuel $\mathrm{CO}_{2}$ gridded emissions data product for tracer transport simulations and surface flux inversions, Earth Syst. Sci. Data, 10, 87-107, https://doi.org/10.5194/essd-10-872018, 2018.

Pacala, S. W., Breidenich, C., Brewer, P. G., Fung, I., Gunson, M. R., Heddle, G., Law, B., Marland, G., Paustian, K., Prather, M., Randerson, J. T., Tans, P., Wofsy, S. C., Linn, A. M., Sturdivant, J., and Al, E.: Verifying Greenhouse Gas Emissions: Methods to Support International Climate Agreements, The National Academies Press, available at: http://www.nap.edu/ catalog/12883.html (last access: 3 November 2020), 2010.

Pathakoti, M., Muppalla, A., Hazra, S., Dangeti, M., Shekhar, R., Jella, S., Mullapudi, S. S., Andugulapati, P., and Vijayasundaram, U.: An assessment of the impact of a nationwide lockdown on air pollution - a remote sensing perspective over India, Atmos. Chem. Phys. Discuss. [preprint], https://doi.org/10.5194/acp-2020-621, 2020.

Petetin, H., Bowdalo, D., Soret, A., Guevara, M., Jorba, O., Serradell, K., and Pérez García-Pando, C.: Meteorologynormalized impact of the COVID-19 lockdown upon $\mathrm{NO}_{2}$ pollution in Spain, Atmos. Chem. Phys., 20, 11119-11141, https://doi.org/10.5194/acp-20-11119-2020, 2020.

Pillai, D., Gerbig, C., Ahmadov, R., Rödenbeck, C., Kretschmer, R., Koch, T., Thompson, R., Neininger, B., and Lavrié, J. V.: High-resolution simulations of atmospheric $\mathrm{CO}_{2}$ over complex terrain - representing the Ochsenkopf mountain tall tower, Atmos. Chem. Phys., 11, 7445-7464, https://doi.org/10.5194/acp11-7445-2011, 2011.

Pillai, D., Gerbig, C., Kretschmer, R., Beck, V., Karstens, U., Neininger, B., and Heimann, M.: Comparing Lagrangian and Eulerian models for $\mathrm{CO}_{2}$ transport - a step towards Bayesian inverse modeling using WRF/STILT-VPRM, Atmos. Chem. Phys., 12, 8979-8991, https://doi.org/10.5194/acp-128979-2012, 2012.

Pillai, D., Buchwitz, M., Gerbig, C., Koch, T., Reuter, M., Bovensmann, H., Marshall, J., and Burrows, J. P.: Tracking city $\mathrm{CO}_{2}$ emissions from space using a high-resolution inverse modelling approach: a case study for Berlin, Germany, Atmos. Chem. Phys., 16, 9591-9610, https://doi.org/10.5194/acp-169591-2016, 2016.

Prairie, Y. T. and Duarte, C. M.: Direct and indirect metabolic $\mathrm{CO}_{2}$ release by humanity, Biogeosciences, 4, 215-217, https://doi.org/10.5194/bg-4-215-2007, 2007.

Roest, G. S., Gurney, K. R., Miller, S. M., and Liang, J.: Informing urban climate planning with high resolution data: the Hestia fossil fuel $\mathrm{CO}_{2}$ emissions for Baltimore, Maryland, Carbon Balance Manage., 15, 22, https://doi.org/10.1186/s13021-02000157-0, 2020.

Serebritsky, I. A. (Ed.): The Report on Environmental Conditions in St. Petersburg for 2017, available at: https://www.gov.spb.ru/static/writable/ckeditor/uploads/2018/ 06/29/Doklad_EKOLOGIA2018.pdf (last access: 3 November 2020), 2018 (in Russian).

Serebritsky, I. A. (Ed.): The Report on Environmental Conditions in St. Petersburg for 2018, available at: https:/www.gov.spb.ru/static/writable/ckeditor/uploads/2019/ 08/12/42/doklad_za_2018_EKOLOGIA2019.pdf (last access: 3 November 2020), 2019 (in Russian).

Sha, M. K., De Mazière, M., Notholt, J., Blumenstock, T., Chen, H., Dehn, A., Griffith, D. W. T., Hase, F., Heikkinen, P., Hermans, C., 
Hoffmann, A., Huebner, M., Jones, N., Kivi, R., Langerock, B., Petri, C., Scolas, F., Tu, Q., and Weidmann, D.: Intercomparison of low- and high-resolution infrared spectrometers for groundbased solar remote sensing measurements of total column concentrations of $\mathrm{CO}_{2}, \mathrm{CH}_{4}$, and $\mathrm{CO}$, Atmos. Meas. Tech., 13, 4791-4839, https://doi.org/10.5194/amt-13-4791-2020, 2020.

Shevlyagina, M.: The real population of St. Petersburg exceeds 7 million people, available at: https://spbdnevnik.ru/news/2020-02-27/ realnoe-naselenie-peterburga-prevyshaet-7-millionov-chelovek, last access: 29 March 2021 (in Russian).

Silva, S. J., Arellano, A. F., and Worden, H. M.: Toward anthropogenic combustion emission constraints from space-based analysis of urban $\mathrm{CO}_{2} / \mathrm{CO}$ sensitivity, Geophys. Res. Lett., 40, 49714976, 2013

Solodilov, V. V.: Analytical note "Transport and communication basis for the coordinated development of Moscow and St. Petersburg", available at: http://www.csr-nw.ru/files/csr/file_category_ 317.pdf (last access: 3 November 2020), 2005 (in Russian).

Stanley, K. M., Grant, A., O’Doherty, S., Young, D., Manning, A. J., Stavert, A. R., Spain, T. G., Salameh, P. K., Harth, C. M., Simmonds, P. G., Sturges, W. T., Oram, D. E., and Derwent, R. G.: Greenhouse gas measurements from a UK network of tall towers: technical description and first results, Atmos. Meas. Tech., 11, 1437-1458, https://doi.org/10.5194/amt-11-1437-2018, 2018.

Stein, A. F., Draxler, R. R., Rolph, G. D., Stunder, B. J. B., and Cohen, M. D., and Ngan, F.: NOAA's HYSPLIT atmospheric transport and dispersion modeling system, B. Am. Meteorol. Soc., 96, 2059-2077, https://doi.org/10.1175/BAMS-D14-00110.1, 2015.

St. Petersburg Center for Information and Analytics: Report on Demographic monitoring in St. Petersburg: Q3 2020, available at: https://www.gov.spb.ru/helper/new_stat/ (last access: 3 November 2020), 2020 (in Russian).

TCCON: Total Carbon Column Observing Network, available at: http://tccon.caltech.edu/, last access: 19 March 2021.

Turnbull, J., Sweeney, C., Karion, A., Newberger, T., Tans, P.,Lehman, S., Davis, K. J., Miles, N. L., Richardson, S. J., Lauvaux, T., Cambaliza, M. O., Shepson, P., Gurney, K., Patarasuk, R., and Zondervan, A.: Towards quantification and source sector identification of fossil fuel $\mathrm{CO}_{2}$ emissions from an urban area: Results from the INFLUX experiment, J. Geophys. Res.-Atmos., 120, 292-312, https://doi.org/10.1002/2014JD022555, 2014.
Umezawa, T., Matsueda, H., Oda, T., Higuchi, K., Sawa, Y., Machida, T., Niwa, Y., and Maksyutov, S.: Statistical characterization of urban $\mathrm{CO}_{2}$ emission signals observed by commercial airliner measurements, Nature, Sci. Rep., 10, 7963, https://doi.org/10.1038/s41598-020-64769-9, 2020.

UN: United Nations, Department of Economic and Social Affairs, Population Division: World Urbanization Prospects 2018: Highlights, available at: https://population.un.org/wup/Publications/ Files/WUP2018-Highlights.pdf, last access: 29 March 2021.

UNFCCC: Paris Agreement, FCCC/CP/2015/L.9/Rev1, available at: http://unfccc.int/resource/docs/2015/cop21/eng/109r01. pdf (last access: 20 May 2020), 2015.

Vogel, F. R., Frey, M., Staufer, J., Hase, F., Broquet, G., XuerefRemy, I., Chevallier, F., Ciais, P., Sha, M. K., Chelin, P., Jeseck, P., Janssen, C., Té, Y., Groß, J., Blumenstock, T., Tu, Q., and Orphal, J.: $\mathrm{XCO}_{2}$ in an emission hot-spot region: the COCCON Paris campaign 2015, Atmos. Chem. Phys., 19, 3271-3285, https://doi.org/10.5194/acp-19-3271-2019, 2019.

Widory, D. and Javoy, M.: The carbon isotope composition of atmospheric $\mathrm{CO}_{2}$ in Paris, Earth Planet. Sc. Lett., 215, 289-298, https://doi.org/10.1016/S0012-821x(03)00397-2, 2003.

WMO Greenhouse Gas Bulletin: 22 November 2018, 14, 1-8, available at: https://library.wmo.int/doc_num.php?explnum_id=5455 (last access: 21 May 2020), 2018.

Wunch, D., Wennberg, P. O., Toon, G. C., Keppel-Aleks, G., and Yavin, Y. G.: Emissions of greenhouse gases from a North American megacity, Geophys. Res. Lett., 36, L15810, https://doi.org/10.1029/2009GL039825, 2009.

Zimnoch, M., Godlowska, J., Necki, J. M., and Rozanski, K.: Assessing surface fluxes of $\mathrm{CO}_{2}$ and $\mathrm{CH}_{4}$ in urban environment: a reconnaissance study in Krakow, Southern Poland, Tellus, 62B, 573-580, https://doi.org/10.1111/j.16000889.2010.00489.x, 2010.

Zinchenko, A. V., Paramonova, N. N., Privalov, V. I., and Reshetnikov, A. I.: Estimation of Methane Emissions in the St. Petersburg, Russia, Region: An Atmospheric Nocturnal Boundary Layer Budget Approach, J. Geophys. Res., 107, D20, https://doi.org/10.1029/2001JD001369, 2002. 